\title{
Regulation of mRNA Translation by Signaling Pathways
}

\author{
Philippe P. Roux ${ }^{1,2,3}$ and Ivan Topisirovic ${ }^{4,5}$ \\ ${ }^{1}$ Institute for Research in Immunology and Cancer, Université de Montréal, Montréal, Québec H3C 3J7, Canada \\ ${ }^{2}$ Molecular Biology Program, Université de Montréal, Montréal, Québec H3C 3J7, Canada \\ ${ }^{3}$ Department of Pathology and Cell Biology, Faculty of Medicine, Université de Montréal, Montréal, \\ Québec H3C 3J7, Canada \\ ${ }^{4}$ Lady Davis Institute for Medical Research, Jewish General Hospital, McGill University, Montréal, \\ Québec H3T 1E2, Canada \\ ${ }^{5}$ Department of Oncology, McGill University, Montréal, Québec H3T 1E2, Canada \\ Correspondence: philippe.roux@umontreal.ca; ivan.topisirovic@mcgill.ca
}

mRNA translation is the most energy consuming process in the cell. In addition, it plays a pivotal role in the control of gene expression and is therefore tightly regulated. In response to various extracellular stimuli and intracellular cues, signaling pathways induce quantitative and qualitative changes in mRNA translation by modulating the phosphorylation status and thus the activity of components of the translational machinery. In this work we focus on the phosphoinositide 3-kinase (PI3K)/AKT and the mitogen-activated protein kinase (MAPK) pathways, as they are strongly implicated in the regulation of translation in homeostasis, whereas their malfunction has been linked to aberrant translation in human diseases, including cancer.

$T^{r}$ anslation plays an evolutionarily conserved role in the regulation of gene expression (Mathews et al. 2007). In fact, recent findings indicate that translation plays a major part in determining protein expression levels in mammalian cells (Schwanhausser et al. 2011). Amperometric oxygen consumption measurements in rat thymocytes revealed that translation consumes $\sim 20 \%$ of cellular ATP, and is thus thought to be the most energy demanding cellular process (Buttgereit and Brand 1995). Therefore, it is not surprising that translation represents a tightly regulated cellular process, dysregulation of which contributes to diverse human diseases, including cancer (see Silvera et al. 2010; Braun et al. 2012).

Translation occurs in three distinct steps: initiation, elongation, and termination (Sonenberg et al. 2012). Although all of the steps are highly regulated, most of the translational control occurs at the rate-limiting initiation step, during which mRNAs and $\mathrm{tRNA}_{\mathrm{i}}^{\mathrm{Met}}$ are recruited to the ribosome through the highly orchestrated action of translation initiation factors (IFs) (reviewed by Sonenberg and Hinnebusch 2009). Various stimuli including environmental stress

Editors: John W.B. Hershey, Nahum Sonenberg, and Michael B. Mathews

Additional Perspectives on Protein Synthesis and Translational Control available at www.cshperspectives.org

Copyright (C) 2012 Cold Spring Harbor Laboratory Press; all rights reserved; doi: 10.1101/cshperspect.a012252

Cite this article as Cold Spring Harb Perspect Biol 2012;4:a012252 
P.P. Roux and I. Topisirovic

(e.g., heat-shock, UV irradiation), extracellular stimuli (e.g., nutrients, hormones, growth factors), and intracellular cues (e.g., energy status of the cell, intracellular availability of amino acids) (Wek et al. 2006; Ma and Blenis 2009; Sonenberg and Hinnebusch 2009) induce dramatic qualitative and quantitative changes in the translatome, i.e., the pools of cellular mRNAs that are being actively translated (Greenbaum et al. 2001). This is achieved in part via the phosphorylation of eukaryotic translation initiation factors (eIFs) and proteins that regulate their activity (e.g., 4E-BPs, PDCD4) by signaling pathways (reviewed by Sonenberg and Hinnebusch 2009; Jackson et al. 2010).

Here we summarize current knowledge on the role of cellular signaling pathways in translational control. In particular, we portray the role of the target of rapamycin (TOR) and the mitogen-activated protein kinase (MAPK) pathways in the regulation of translation, because these pathways regulate the phosphorylation and function of a multitude of eIFs and associated factors. Another important signaling node in translation involves the eIF2 $\alpha$ kinases, discussed by Benham (2012).

\section{TOR}

TOR is an evolutionarily conserved Ser/Thr kinase, which regulates proliferation (increase in cell number) and growth (increase in volume/ mass) in response to cellular energy status, growth factors, hormones, and nutrient availability (Wullschleger et al. 2006). TOR exists in two functionally and structurally distinct protein complexes referred to as TOR complex 1 and 2 (TORC1 and 2) (Wullschleger et al. 2006). In mammalian cells, mechanistic/mammalian TORC1 (mTORC1) consists of the catalytic component mTOR, the scaffolding protein Raptor (regulatory-associated protein of TOR, which is orthologous to KOG1 in yeast), the GTPase $\beta$-subunit like protein $\mathrm{g} \beta \mathrm{L}$ (also known as mLST8), proline-rich AKT substrate of $40 \mathrm{kDa}$ (PRAS40) and Deptor (disheveled, Egl-10, pleckstrin [DEP] domain containing mTOR interacting protein) (Fig. 1) (Guertin and Sabatini 2007; Peterson et al. 2009).
mTOR, g $\beta$ L, and Deptor are also found in mTORC2 (Guertin and Sabatini 2007; Peterson et al. 2009). In turn, Rictor (rapamycin-insensitive companion of TOR, which is orthologous to AVO3 in yeast), mSIN1 (mammalian stressactivated protein kinase (SAPK)-interacting protein), and PRR5 (Proline-rich protein 5, also known as Protor) (Frias et al. 2006; Jacinto et al. 2006; Pearce et al. 2007; Thedieck et al. 2007; Woo et al. 2007) are found exclusively in mTORC2 (Fig. 2). mTORC1 and mTORC2 regulate disparate cellular functions by phosphorylating distinct sets of substrates. Several substrates of mTORC1 have been identified in the past two decades including the eIF4E-binding proteins (4E-BPs), $70 \mathrm{kDa}$ ribosomal 66 kinases 1 and 2 (S6Ks), PRAS40, Ser/Thr kinase Ulk1 (also known as hATG1), and growth factor receptor-bound protein 10 (Grb10) (reviewed by Caron et al. 2010; Yea and Fruman 2011; Zon$\mathrm{cu}$ et al. 2011b). By modulating their activity, mTORC1 regulates a variety of cellular processes including growth, proliferation, translation, autophagy, as well as its own activation (Zoncu et al. 2011b). The function, upstream regulators, and associated substrates of mTORC2 are less well understood (Oh and Jacinto 2011). mTORC2 phosphorylates AGC kinase family members, e.g., AKT, protein kinase C (PKC) and serum/glucocorticoid regulated kinase 1 (SGK1) and thereby controls cytoskeletal organization and cell survival (Sarbassov et al. 2004; Sarbassov et al. 2005; Guertin and Sabatini 2007; Garcia-Martinez and Alessi 2008). mTORC2 also associates with the ribosome (Zinzalla et al. 2011) where it phosphorylates residues in nascent polypeptide chains that are important for optimal protein folding (Fig. 2) (Oh et al. 2010).

mTORC1 and mTORC2 exhibit differential sensitivity to rapamycin. Rapamycin is a naturally occurring allosteric inhibitor of mTORC1 (Hay and Sonenberg 2004; Petroulakis et al. 2006; Guertin and Sabatini 2009). It forms a complex with its intracellular receptor, FKBP12 (FK506-binding protein of $12 \mathrm{kDa}$ ), which binds to the FRB (FKBP12-rapamycin binding) domain of mTOR and inhibits mTORC1 function (Chen et al. 1995). Although the precise 
Signaling to the Translational Machinery

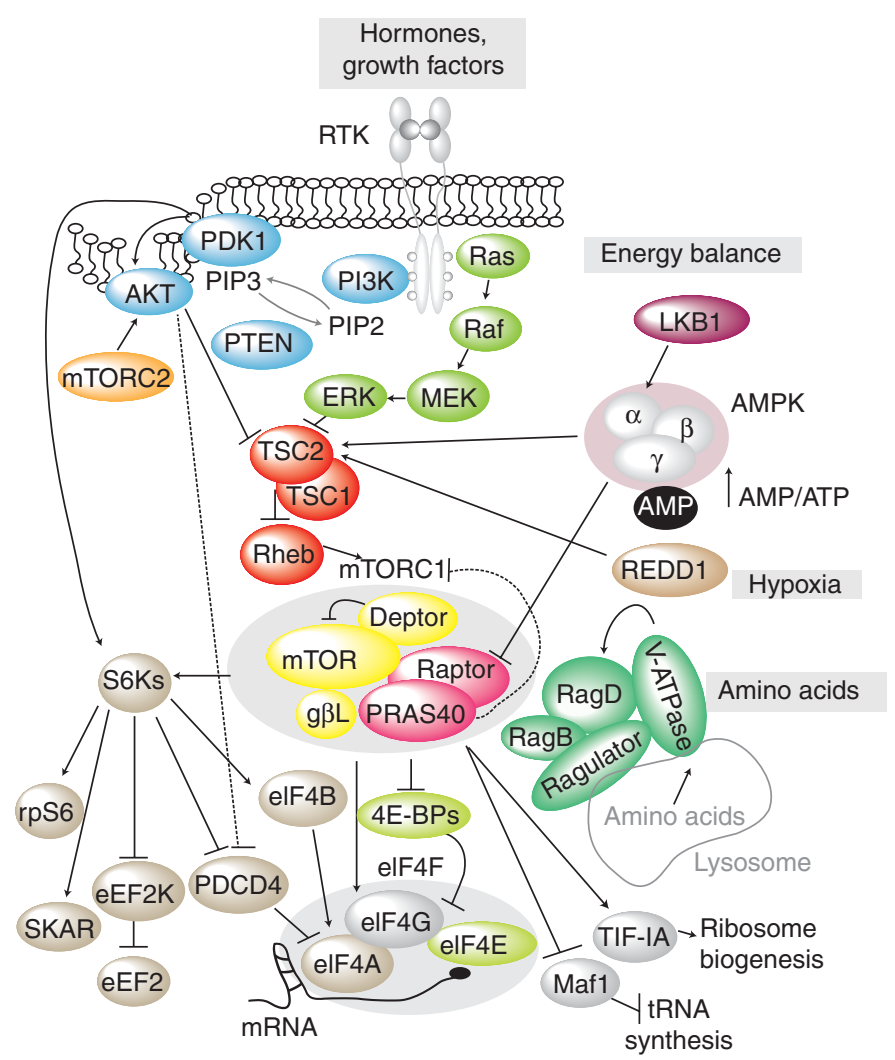

Figure 1. Schematic representation of mTORC1 signaling to the translational machinery. Growth factors and hormones stimulate mTORC1 by activating receptor tyrosine kinase (RTK) signaling via PI3K/AKT (light blue) and Ras/ERK (green) pathways. mTORC1 is also activated by amino acids via small Rag GTPases (aquamarine). Insufficient energy resources and hypoxia inactivate mTORC1 via the LKB1/AMPK pathway (purple) and REDD1 (brown), respectively. TSC1/2 (red) suppresses mTORC1 signaling by inhibiting GTPase activity of Rheb (red). mTORC1 modulates translation via the phosphorylation of downstream targets including 4E-BPs (olive), S6Ks (champagne), and their downstream effectors. In addition, mTORC1 stimulates ribosome biogenesis and tRNA synthesis by activating TIF-IA (gray) and inhibiting Mafl (gray), respectively. mTOR, Deptor, and gßL (yellow) are found in both mTORC1 and mTORC2, whereas PRAS40 and Raptor are specific components of $\mathrm{mTORC1}$ (pink). T bars represent inhibitory signals, whereas arrows indicate stimulatory signals. Abbreviations and detailed explanations are provided in the text.

mechanism of inhibition remains incompletely defined, rapamycin:FKBP12 binding to the FRB domain was shown to weaken the mTOR:Raptor interaction and partially reduce intrinsic mTORC1 catalytic activity, as measured by mTOR autophosphorylation at Ser2481 (Soliman et al. 2010; Yip et al. 2010). Recent studies, however, revealed that the inhibition of mTORC1 by rapamycin is incomplete, inasmuch as it efficiently suppresses the phosphorylation of S6Ks, but not of 4E-BPs (Choo et al.
2008). In contrast to mTORC1, mTORC2 appears to be largely insensitive to the effects of rapamycin in acute treatment. However, it was proposed that prolonged rapamycin treatment results in inhibition of mTORC2 signaling in a cell type-specific manner, likely by blunting its de novo assembly (Sarbassov et al. 2006).

mTORC1 plays a central role in the regulation of cell growth and proliferation (Fingar and Blenis 2004; Ma and Blenis 2009; Zoncu et al. 2011b), cellular processes that are directly 
P.P. Roux and I. Topisirovic

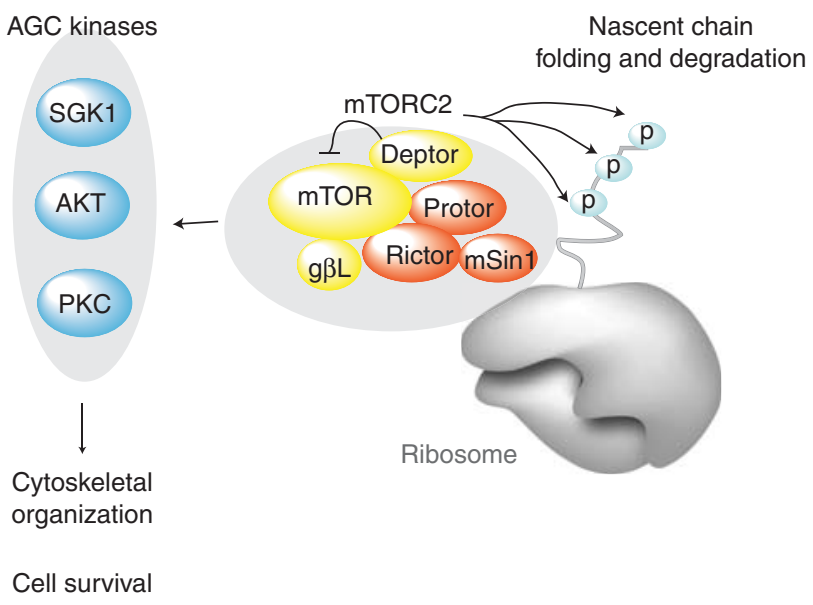

Figure 2. Schematic representation of mTORC2 signaling pathway. Cellular functions of mTORC2 are described less well than those of mTORC1. Protor, Rictor, and mSin1 (orange) are specific components of mTORC2. mTORC2 stimulates the activity of AGC kinase family members (blue) by phosphorylating residues localized in their hydrophobic motifs. Phosphorylation of PKC, AKT, and SGK1 by mTORC2 is thought to influence cytoskeletal organization and cell survival, respectively. In addition, it was recently reported that mTORC2 associates with the ribosome. It appears that ribosome-localized mTORC2 cotranslationally phosphorylates nascent polypeptide chains as they emerge from the ribosome thus facilitating their optimal folding. Upstream regulators of mTORC2 are still largely elusive. T bars represent inhibitory signals, whereas arrows indicate stimulatory signals. Abbreviations and detailed explanations are provided in the text.

proportional to translational activity (Brooks 1977; Zetterberg et al. 1995). Growth factors, hormones, branched-chain amino acids, and glucose stimulate mTORC1, up-regulate translation, and stimulate cellular growth and proliferation (reviewed by Zoncu et al. 2011b). Conversely, under conditions in which energy production, oxygen supply, and nutrients are inadequate, mTORC1 signaling is down-regulated, resulting in inhibition of translation, reduction in cellular growth proliferation, and induction of autophagy (reviewed by Zoncu et al. 2011b). Autophagy is the major catabolic process in the cell, during which cytoplasmic organelles and macromolecular complexes are degraded to replenish intracellular pools of amino acids (Stipanuk 2009).

\section{Upstream of mTORC1}

mTORC1 signaling to the translational apparatus is modulated via a multitude of cellular pathways including phosphoinositide 3-kinase
(PI3K), Ras/MAPK, Rag GTPases, and adenosine monophosphate (AMP)-activated protein kinase (AMPK) (Fig. 1) (Hay and Sonenberg 2004; Laplante and Sabatini 2009).

\section{Growth Factors and Hormones}

Hormones and growth factors [e.g., insulin and insulin-like growth factors (IGFs)] activate PI3K via receptor tyrosine kinases (RTKs; such as insulin- or IGF-receptor) and associated adaptor molecules (e.g., IRS-1 and -2). PI3K converts phosphatidylinositol 4,5-bisphosphate $\left(\mathrm{PIP}_{2}\right)$ into phosphatidylinositol-3,4,5-triphosphate $\left(\mathrm{PIP}_{3}\right)$ (reviewed by Cantley 2002; Engelman et al. 2006), which is reversed by the tumor suppressor phosphatase and tensin homolog [PTEN; (Maehama and Dixon 1998)]. PIP 3 binds the pleckstrin homology domains of PDK1 and AKT resulting in their recruitment to the plasma membrane (Cantley 2002; Engelman et al. 2006). The Ser/Thr kinase PDK1 phosphorylates AKT and other AGC-kinases 
(e.g., PKC, RSK, and S6K) on residues localized in their activation loops (e.g., Thr308 in human AKT1) (reviewed by Pearce et al. 2010). In addition, mTORC2 modulates the activity of AKT by phosphorylating a serine residue in its hydrophobic motif (Ser473 in human AKT1) (Sarbassov et al. 2005). TSC1/2 is comprised of the scaffolding protein TSC1 (hamartin) and the GTPase activating protein (GAP) TSC2 (tuberin) (Kwiatkowski and Manning 2005). AKT phosphorylates TSC2 at multiple sites, which are thought to inhibit its GAP activity, thus reducing Ras homolog enriched in brain (Rheb)-GTP hydrolysis to its inactive GDP-bound form (Manning et al. 2002; Garami et al. 2003; Inoki et al. 2003). Rheb is a small GTPase (Yamagata et al. 1994) that activates mTORC1 through a poorly understood mechanism (Inoki et al. 2003). A single gene coding for Rheb is found in yeast and Drosophila, whereas mammalian cells express two variants of this protein, Rheb1 and Rheb2 (reviewed by Avruch et al. 2006).

PRAS40 is a recently identified suppressor of mTORC1 (Fonseca et al. 2007; Oshiro et al. 2007; Sancak et al. 2007; Vander Haar et al. 2007; Wang et al. 2007). PRAS40 is phosphorylated on Thr246 via PI3K/AKT, which suggests that it acts as an upstream inhibitor of mTORC1 (Sancak et al. 2007; Vander Haar et al. 2007). However, PRAS40 binds Raptor via a TOR signaling (TOS) motif, which is present in other mTORC1 substrates such as 4E-BPs and S6Ks (Schalm and Blenis 2002; Schalm et al. 2003) and is phosphorylated by mTORC1 at multiple sites, including rapamycin-sensitive (Ser183 and Ser221) and -insensitive (Ser212) residues (Oshiro et al. 2007; Wang et al. 2007). These findings suggest a model whereby PRAS40 acts as a downstream target of mTORC1, which competes with 4E-BPs and S6Ks for binding to Raptor (Fig. 1). Accordingly, phosphorylation and release of PRAS40 from mTORC1 increases substrate accessibility but does not increase its kinase activity (Rapley et al. 2011).

Growth factors also stimulate mTORC1 activity through a pathway involving the small Ras GTPases (reviewed by Shaw and Cantley 2006). Loss of the tumor suppressor gene NF1, which encodes a Ras GAP, results in increased mTORC1 signaling and tumorigenesis (Johannessen et al. 2005, 2008). Ras is an oncogene that triggers several signaling cascades, including the MAPK pathway, which consists of the sequential activation of the Raf, MEK, and ERK protein kinases (Rajalingam et al. 2007). At present, it is not clear how ERK1/2 stimulate mTORC1 activity, but TSC2 was shown to be a direct target of ERK1/2 and its downstream substrate, the $90 \mathrm{kDa}$ ribosomal S6 kinase (RSK) (Roux et al. 2004; Ballif et al. 2005; Ma et al. 2005). Both protein kinases also phosphorylate Raptor at regulatory sites, correlating with increased mTORC1 activity and signaling to downstream substrates (Carriere et al. 2008a, 2011). Recent evidence suggests that RSK also phosphorylates Deptor within a degron sequence that is recognized by the E3-ubiquitin ligase $\mathrm{SCF}^{\beta \mathrm{TrCP}}$, thereby promoting its ubiquitination and proteosomal degradation (Zhao et al. 2011).

\section{Nutrients, Oxygen, and Energy Status in the Cell}

mTORC1 controls cellular proliferation and growth in response to nutrient availability and cellular energy balance (Fig. 1). Amino acids, in particular those with a branched side chain, are indispensable for mTORC1 signaling in cell culture (Hara et al. 1998; Wang et al. 1998). In yeast, amino acids stimulate Vam6/VPS39, which loads GTP onto Gtr1/Gtr2 GTPases (Binda et al. 2009). Gtr1/Gtr2 are components of the vacuolar-membrane-associated EGO complex, which binds to and activates TORC1 (Kim and Guan 2011). A similar mechanism has recently been described in mammals, whereby in response to amino acids Rag GTPases recruit mTORC1 to lysosomal membranes via interaction with Raptor (Sancak et al. 2008). This brings mTORC1 into close proximity of Rheb resulting in its activation (Kim et al. 2008; Sancak et al. 2008). Analogous to Gtr1/Gtr2, Rags form heterodimers comprising RagA or RagB bound to RagC or RagD, whose activity is governed by the scaffolding Ragulator complex (Sengupta et al. 2010), which consists of the $\mathrm{p} 18, \mathrm{p} 14$, and MP1 proteins and is required for 
P.P. Roux and I. Topisirovic

the anchoring of Rags to the lysosome (Sancak et al. 2010). Vacuolar $\mathrm{H}^{+}$-ATPase (v-ATPase) associates with the Ragulator complex and plays an essential role in conducting amino acid signals from the lysosomal lumen to Rags (Zoncu et al. 2011a). In addition, it has been reported that signaling adaptor p62 interacts with Raptor, mediates the interaction of mTOR with Rag GTPases, and stimulates translocation of mTORC1 to the lysosome (Duran et al. 2011).

Glucose deprivation leads to a decrease in glucose flux and cellular ATP levels, thus inhibiting mTORC1 signaling (Fig. 1). Changes in cellular energy balance impact on mTORC1 signaling via AMPK, which is a Ser/Thr kinase consisting of a catalytic $\alpha$-subunit and two regulatory subunits, $\beta$ and $\gamma$ (Kahn et al. 2005; Shaw 2009). AMPK is activated under conditions in which the intracellular AMP/ATP ratio is increased (e.g., lack of nutrients, mitochondrial dysfunction) (Kahn et al. 2005; Shaw 2009). AMP directly associates with the $\gamma$-subunit of AMPK, thus facilitating the phosphorylation of the $\alpha$-subunit on Thr172 by upstream kinases such as Serine/Threonine kinase 11 (STK11/ LKB1) (Shaw 2009). On activation, AMPK suppresses anabolic processes including protein synthesis and restricts proliferation and growth (Kahn et al. 2005; Shaw 2009). This is partly achieved via inhibition of mTORC1 (Shaw et al. 2004). AMPK inhibits mTORC1 by phosphorylating and activating TSC2 (Corradetti et al. 2004) and by phosphorylating Raptor resulting in its sequestration by 14-3-3 proteins (Gwinn et al. 2008). Inhibition of mTORC1 signaling appears to be required for the block in proliferation exerted by AMPK (Gwinn et al. 2008), which is paralleled by a decrease in global translation (Dowling et al. 2007). These results suggest that the AMPK/mTOR pathway connects the regulation of intracellular energy balance with translational control and cell proliferation.

Under conditions where the supply of oxygen is limited, mTORC1 signaling is suppressed via multiple mechanisms (Fig. 1). In addition to inhibiting oxidative phosphorylation and, as a result, activating AMPK, hypoxia represses mTORC1 signaling through regulated in devel- opment and DNA damage response 1 (REDD1) (Brugarolas et al. 2004). REDD1 expression is stimulated by several cellular insults (Ellisen et al. 2002) and was shown to inhibit mTORC1 by stabilizing the TSC1/2 complex (DeYoung et al. 2008). Additional inhibitory mechanisms were described to occur during hypoxia, including the direct interaction and inhibition of Rheb by the hypoxia-inducible proapoptotic protein BNIP3 (BCl2/adenovirus E1B $19 \mathrm{kDa}$ proteininteracting protein 3) (Li et al. 2007).

It is worthwhile to note that because of nonphysiological conditions used in the aforementioned in vitro studies (i.e., glucose and amino acid deprivation followed by acute refeeding), the understanding of how mTORC1 is regulated by nutrients and alterations in the energy balance in vivo is still incomplete. Indeed, recent studies suggest that the regulation of $\mathrm{mTORC1}$ signaling by nutrients at the organismal level is more complex than initially thought (reviewed by Howell and Manning 2011).

\section{Emerging Mechanisms of mTORC1 Regulation}

mTOR activity is regulated by the phosphorylation of residues located within its kinase domain (Ser2159 and Thr2164 in human mTOR) (Ekim et al. 2011). Phosphorylation of these residues stimulates mTOR autophosphorylation (on Ser2481 in human protein) (Soliman et al. 2010) and is required for its effects on cell growth and proliferation (Ekim et al. 2011). The identity of the mTOR Ser2159 andThr2164 kinase(s) remains unknown. Phosphorylation of mTOR at Ser1261, which lies in a centrally located HEAT (Huntington, Elongation Factor 3, PR65/A, TOR)-repeat, also promotes mTORC1 signaling, mTOR autophosphorylation at Ser2461 and cell growth (Acosta-Jaquez et al. 2009). mTOR also phosphorylates Raptor on several sites (including Ser863 in human Raptor) that, in turn, increases mTOR activity toward downstream substrates (Foster et al. 2010). Interestingly, ERK1/2 were also shown to phosphorylate some of these sites (Carriere et al. 2011), but the physiological relevance of this additional layer of regulation remains unknown. 
mTORC1 Signaling to the Translational Machinery

mTORC1 stimulates global protein synthesis, as well as translation of a specific subset of mRNAs (Fig. 3). 4E-BPs and S6Ks are the most extensively studied and best-understood downstream effectors of mTORC1, which have been implicated in the regulation of translation (Hay and Sonenberg 2004).

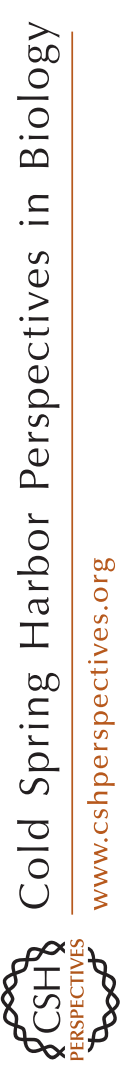

$4 E-B P S$

The first step of cap-dependent translation initiation is the assembly of the eIF4F complex on the $5^{\prime}$-mRNA cap structure (Mathews et al. 2007; Sonenberg and Hinnebusch 2009; Jackson et al. 2010; Topisirovic et al. 2011). The eIF4F complex comprises the cap-binding subunit eIF4E, the large scaffolding protein eIF4G, and the DEAD-box RNA helicase eIF4A, which unwinds secondary structure within the $5^{\prime}$-untranslated region ( $5^{\prime} \mathrm{UTR}$ ) of the mRNA (Fig. 3A) (Gingras et al. 1999b; Sonenberg and Hinnebusch 2009; Jackson et al. 2010). 4E-BPs are small-molecular weight translational repressors (4E-BP1, 2, and 3 in mammals), which interfere with the assembly of the eIF4F complex by competing with eIF4G for binding to eIF4E (Pause et al. 1994). On activation, mTORC1 phosphorylates residues corresponding to Thr37 and Thr46 on human 4E-BP1, which act as priming sites for the phosphorylation of Ser65 and Thr70 (Fig. 3A) (Gingras et al. 1999a, 2001). Phosphorylation of $4 \mathrm{E}-\mathrm{BPs}$ on these four residues, leads to their dissociation from eIF4E, thus allowing the assembly of the eIF4F complex (Pause et al. 1994; Gingras et al. 1999a, 2001).

eIF4E is a general translation initiation factor required for cap-dependent translation of all cellular mRNAs (reviewed by Sonenberg and Hinnebusch 2009). Nonetheless, it is well established that alterations in eIF4E levels and/or activity affect translation of a specific pool of "eIF4E-sensitive" mRNAs, but do not have a major impact on global protein synthesis (Graff and Zimmer 2003; De Benedetti and Graff 2004; Graff et al. 2008; Sonenberg and Hinnebusch
2009). It is thought that "eIF4E-sensitivity" of mRNAs is determined by the complexity of their 5'UTRs. "eIF4E-sensitive" mRNAs, which frequently encode proliferation and survival promoting proteins (e.g., Bcl-xL, cyclins, ornithine decarboxylase, c-myc, vascular, and endothelial growth factor), possess long and highly structured 5'UTRs and thus are strongly dependent on the unwinding activity of the eIF4A subunit of eIF4F, whereas "eIF4E-insensitive" mRNAs such as those encoding housekeeping proteins (e.g., actins and tubulins) bear short 5'UTRs and are only minimally sensitive to alterations in eIF4F levels (Fig. 3B) (Koromilas et al. 1992; Svitkin et al. 2001; De Benedetti and Graff 2004; Sonenberg 2008). Because eIF4E is the most limiting factor among eukaryotic translation initiation factors, it controls the levels of eIF4F (reviewed by Sonenberg and Hinnebusch 2009). 4E-BPs impede eIF4F complex assembly (Pause et al. 1994; Gingras et al. 1999a, 2001). Correspondingly, alterations in the expression and/or phosphorylation status of 4E-BPs only marginally affect global protein synthesis, while strongly influencing translation of a subset of mRNAs (e.g., IRF-7, Gas2, cyclin D3, ornithine decarboxylase, and vascular and endothelial growth factor) (Lynch et al. 2004; Colina et al. 2008; Petroulakis et al. 2009; Dowling et al. 2010a). Thus, in addition to its effects on global protein synthesis, mTORC1 selectively stimulates translation of "eIF4E-sensitive" mRNAs by phosphorylating and inactivating 4E-BPs. The vast majority of "eIF4E-sensitive" mRNAs encode proliferation, survival, and tumor-promoting proteins, and accordingly, 4E-BPs act as major mediators of the effects of mTORC1 on proliferation (Dowling et al. 2010a). In Drosophila, dS6K and d4E-BP play overlapping roles in regulating cell size and proliferation downstream from dTOR (Montagne et al. 1999; Miron et al. 2001). In contrast, mammalian 4EBPs do not appear to significantly influence cell size, which is thought to be largely achieved via S6Ks (Pende et al. 2004; Ohanna et al. 2005; Dowling et al. 2010a). The evolutionary advantage of this "division of labor" between $4 \mathrm{E}-\mathrm{BPs}$ and S6Ks downstream from mTORC1 is still unclear. 
P.P. Roux and I. Topisirovic
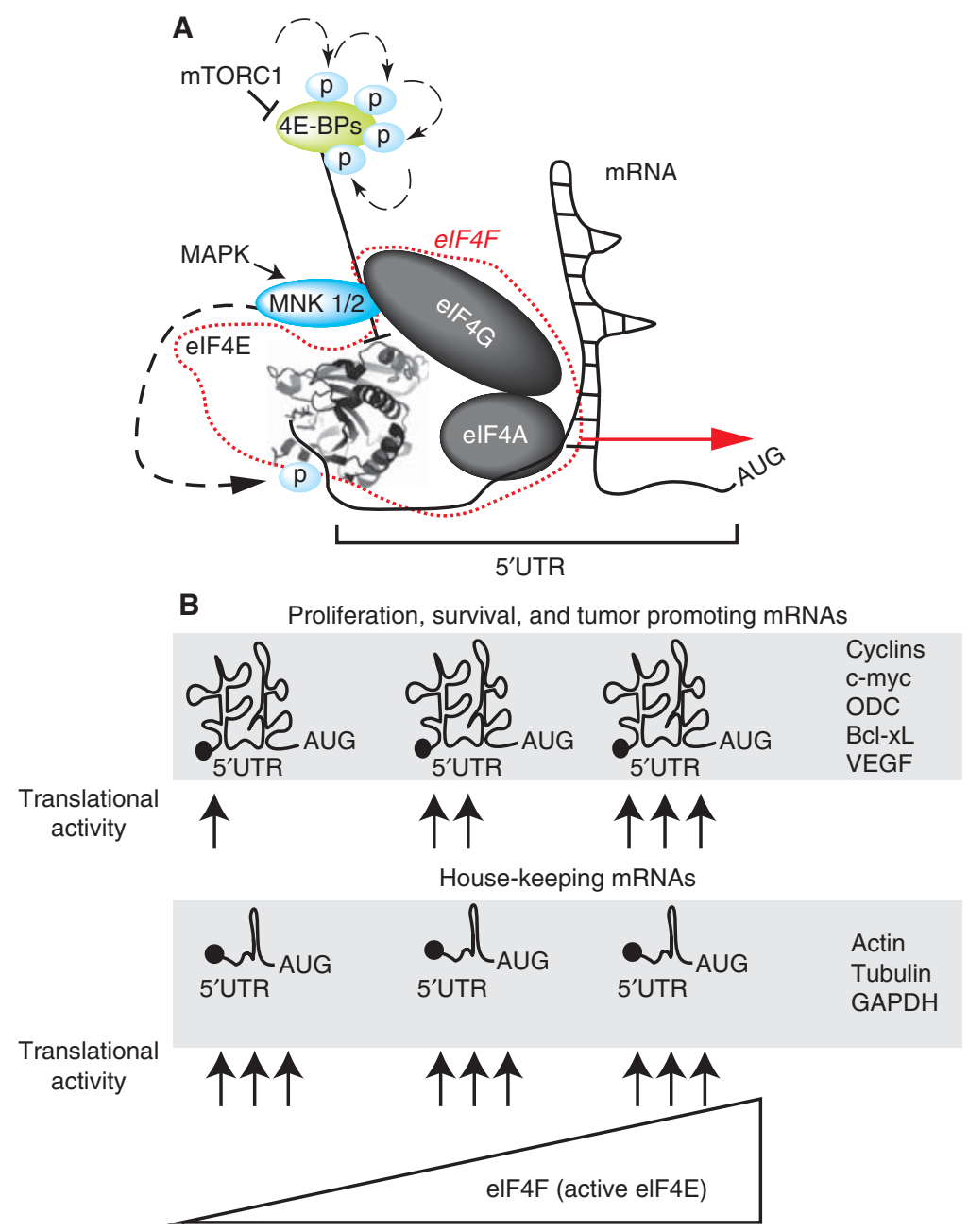

Figure 3. mTORC1 and MAPK pathways modulate translation of a specific subset of mRNAs by stimulating eIF4E activity. (A) Hierarchical phosphorylation of 4E-BPs (green) by mTORC1 (broken arrows) leads to their dissociation from eIF4E, thereby stimulating the interaction of eIF4E with eIF4G and the assembly of the eIF4F complex (red). eIF4E is the most limiting subunit of the eIF4F complex, which is critical for the recruitment of eIF4A to the $5^{\prime} \mathrm{UTR}$ of mRNA and unwinding of the secondary structure during scanning of the ribosome toward the initiation codon (AUG; red arrow). MAPK-interacting kinases 1 and 2 (MNK1/2) (blue) are recruited to eIF4E via eIF4G and phosphorylate eIF4E at a single Ser residue (Ser209 in human eIF4E). (B) mRNAs that contain long and highly structured 5'UTRs frequently encode proliferation, survival, and tumor promoting proteins (top panel). Translation of these mRNAs strongly depends on the unwinding activity of eIF4A, and is thus robustly stimulated by the increase in the amount of eIF4E, which is available for eIF4F complex assembly (further explanation provided in the text). In addition, phospho-eIF4E selectively stimulates translation of Mcl-1, MMP, and proinflammatory mRNAs by a hitherto unknown mechanism. In contrast, housekeeping proteins are typically encoded by mRNAs that bear short, unstructured $5^{\prime}$ UTRs (lower panel) and their translational activity is only marginally influenced by the changes in the availability of eIF4E or its phosphorylation status. The eIF4E diagram was generated using PyMOL software (http://www.pymol.org). eIF4E-PDB accession number 1L8B. 
S6Ks

In addition to $4 \mathrm{E}-\mathrm{BPs}$, TOR regulates translation by activating the S6Ks (Hay and Sonenberg 2004; Ma and Blenis 2009; Dowling et al. 2010b; Zoncu et al. 2011b). Although Drosophila expresses a single $\mathrm{S} 6 \mathrm{~K}$ protein (dS6K), mammals express two variants of S6K (S6K1 and S6K2; or $\mathrm{S} 6 \mathrm{~K} \alpha$ and $\mathrm{S} 6 \mathrm{~K} \beta$, respectively), which are encoded by two distinct genes (RPS6KB1 and RPS6KB2) and share a high degree of homology (reviewed by Fenton and Gout 2011). S6K1 and S6K2 exist in two different isoforms ( $\mathrm{p} 70$ and p85, and p54 and p56, respectively), which are generated via alternative translational initiation sites from a common mRNA (Grove et al. 1991; Gout et al. 1998).p70S6K1 is the more abundant isoform of $\mathrm{S} 6 \mathrm{~K} 1$ and is predominantly cytoplasmic, whereas p85S6K1, p54S6K2, and p56S6K2 are localized in the nucleus (reviewed by Fenton and Gout 2011).

S6Ks belong to the AGC kinase family and are activated by PDK1 and mTORC1 via the phosphorylation of Thr residues localized in their activation loop (Thr229 in human p70S6K1) and hydrophobic motif (Thr389 in human p70S6K1), respectively (reviewed by Fenton and Gout 2011). Recent findings indicate that GSK3 also contributes to the activation of S6Ks through the phosphorylation of their turn motif (Ser371 in human p70S6K1) (Shin et al. 2011a). Several S6Ks substrates have been implicated in the regulation of translation including ribosomal protein S6 (rpS6) (Banerjee et al. 1990; Kozma et al. 1990), eukaryotic initiation factor 4B (eIF4B) (Raught et al. 2004; Shahbazian et al. 2006), and programmed cell death 4 protein (PDCD4) (Dorrello et al. 2006).

rpS6 was the first identified S6K substrate. Five phosphorylation sites (Ser235, Ser236, Ser240, Ser244, and Ser247 in humans and rodents) are clustered in the carboxyl terminus of rpS6 (Meyuhas 2008). It has been proposed that S6Ks phosphorylate rpS6 in a sequential fashion, whereby the phosphorylation of Ser236 is followed by the phosphorylation of Ser235, Ser240, Ser244, and Ser247 (Krieg et al. 1988; Ferrari et al. 1991; Bandi et al. 1993). Although S6K1 contributes to rpS6 phosphorylation, S6K2 appears to be the predominant kinase that phosphorylates rpS6 on these residues (Meyuhas 2008). In contrast, the RSKs phosphorylate rpS6 only on Ser235 and Ser236 (Pende et al. 2004; Roux et al. 2007), but the physiological relevance for this specificity remains unknown. Experiments obtained using mice in which wild-type rpS6 is replaced by a nonphosphorylatable mutant revealed that the loss of rpS6 phosphorylation mirrors defects in cell growth observed in S6K1/2 knockout mice (Ruvinsky et al. 2005). Notwithstanding the overlap in their physiological roles, the understanding of how S6Ks and rpS6 impact translation remains obscure. Loss of S6Ks only modestly affects global translation rates, whereas the expression of the nonphosphorylatable mutant of the rpS6 results in a moderate up-regulation of overall protein synthesis rates (Pende et al. 2004; Ruvinsky et al. 2005). 5'-terminal oligopyrimidine tract (5'-TOP)-containing mRNAs encode components of the translational machinery and their translation is repressed under conditions where S6K activity and rpS6 phosphorylation are minimal, such as when cells are deprived of amino acids (Levy et al. 1991). Thus, it was proposed that S6Ks promote translation of the $5^{\prime}$-TOPmRNAs via stimulation of rpS6 phosphorylation (Kawasome et al. 1998; Shima et al. 1998; Loreni et al. 2000). However, it was subsequently shown that neither the loss of S6Ks nor the phosphorylation status of rpS6 influences translation of 5'-TOP mRNAs (Tang et al. 2001; Pende et al. 2004; Ruvinsky et al. 2005).

PDCD4 plays an established role in apoptosis and has been suggested to possess tumor suppressor properties (reviewed by Lankat-Buttgereit and Goke 2009). PDCD4 binds to eIF4A via two conserved MA-3 domains (also found in eIF4G) and competes with eIF4G for eIF4A binding (Goke et al. 2002; Yang et al. 2003). This leads to the inhibition of eIF4A and the consequent repression of cap-dependent translation (Yang et al. 2003). S6Ks and AKT phosphorylate PDCD4 on Ser67 and Ser457 leading to its degradation by the E3-ubiquitin ligase $\mathrm{SCF}^{\beta \operatorname{TrCP}}$ (Dorrello et al. 2006).

eIF4B and eIF4H are two auxiliary factors that stimulate the RNA unwinding activity of 
eIF4A (Grifo et al. 1984; Rozen et al. 1990; Pause et al. 1994; Richter-Cook et al. 1998; Rogers et al. 2001). eIF4B stimulates cellular proliferation and survival by selectively up-regulating translation of mRNAs such as those encoding Cdc25, ODC, XIAP, and Bcl-2 (Shahbazian et al. 2010). eIF4B is phosphorylated by several AGC kinases on Ser406 (likely by RSK and S6K) and Ser422 (by S6K, AKT, and RSK) in a stimulusand cell type-dependent manner (Raught et al. 2004; Shahbazian et al. 2006; van Gorp et al. 2009). It was suggested that eIF4B phosphorylation promotes its association with eIF3 and correlates with increased translation initiation (Holz et al. 2005; Shahbazian et al. 2006). eIF3 is the multisubunit complex that was also identified as a dynamic scaffold for mTORC1 and S6K1 binding (Holz et al. 2005). On activation, mTORC1 is recruited to the eIF3 complex where it phosphorylates S6K1, leading to its dissociation from eIF3 and subsequent phosphorylation by PDK1 (Holz et al. 2005).

S6Ks also phosphorylate eukaryotic elongation factor 2 (eEF2) kinase at Ser366 (in human eEF2K). eEF2K impedes translation elongation by phosphorylating and inhibiting eEF2 (Wang et al. 2001a), a GTPase that promotes translocation of the nascent polypeptide chain from the A-site to the P-site of the ribosome (Skogerson and Moldave 1968; Bermek and Matthaei 1971). Finally, S6K1 has been shown to promote translational efficiency of newly spliced mRNAs on its recruitment to the exon-junction complex (EJC) by its substrate and binding partner SKAR (Richardson et al. 2004). Recruitment of S6K1 and SKAR to the EJC leads to the phosphorylation of numerous mRNA binding proteins and correlates with increased translational efficiency of spliced mRNAs (Ma et al. 2008).

\section{Additional mTOR Targets Implicated in Translational Control}

Besides 4E-BPs and S6Ks, mTORC1 has been suggested to modulate translational initiation via phosphorylation of eIF4G at multiple residues (Raught et al. 2000). mTORC1 also stimulates ribosome biogenesis and tRNA synthesis, via stimulation of TIF-IA (Mayer et al. 2004) and inhibition of the TF-IIIC repressor Maf1, respectively (Wei et al. 2009; Kantidakis et al. 2010; Michels et al. 2010; Shor et al. 2010).

\section{MAPK SIGNALING TO THE \\ TRANSLATIONAL MACHINERY}

The MAPKs are Ser/Thr kinases that are among the most ancient signal transduction pathways and are widely used throughout evolution in many physiological processes (Widmann et al. 1999). All eukaryotic cells possess multiple MAPK pathways, which coordinate gene expression, mitosis, metabolism, motility, survival, apoptosis, and differentiation. In mammals, 14 MAPKs have been characterized, but the most extensively studied groups are the ERK1/2, JNKs, and p38 isoforms (reviewed by Chen et al. 2001; Kyriakis and Avruch 2001; Pearson et al. 2001). The wide range of functions regulated by these MAPKs is mediated through phosphorylation of several substrates, including members of a family of Ser/Thr kinases termed MAPK-activated protein kinase (MAPKAPK) (Gaestel 2006; Gaestel 2008; Cargnello and Roux 2011). Two MAPKAPKs have been directly implicated in the regulation of translation, namely the RSKs (Carriere et al. 2008b) and the MAPK-interacting kinases (MNKs) (Buxade et al. 2008). Although the RSK isoforms are strictly regulated by ERK1/2 downstream from growth factors and mitogens, the MNKs can be activated by either ERK1/2 or p38 isoforms, making them responsive to both mitogenic and stress stimuli (Fig. 4). The RSKs and MNKs become active on phosphorylation of a threonine residue followed by a proline, located in the activation loop of their kinase domain (Roux and Blenis 2004).

\section{MNKs}

In addition to its regulation by the $4 \mathrm{E}-\mathrm{BPs}$ through mTORC1 signaling, the activity of eIF4E is regulated by MNK1 and MNK2, which phosphorylate a single serine residue in its carboxyl terminus (Fig. 4) (Ser209 in human eIF4E) (Fukunaga and Hunter 1997; Waskiewicz et al. 1997). MNK1 and 2 exist in two isoforms 
Signaling to the Translational Machinery

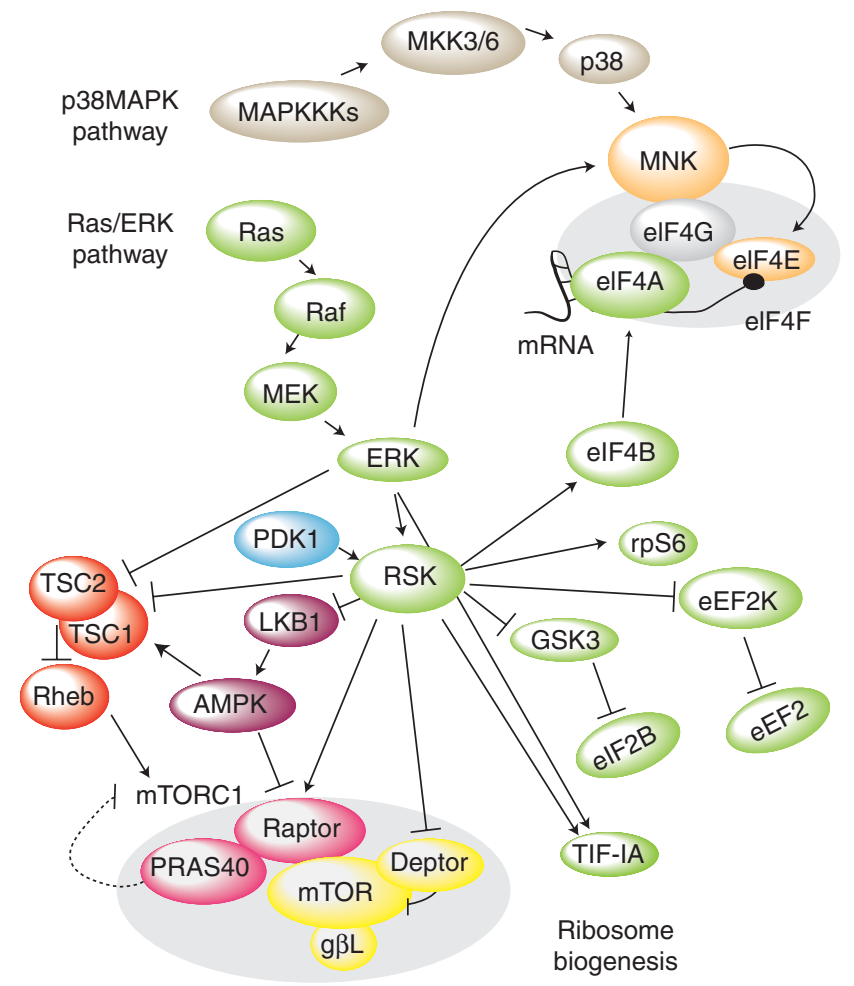

Figure 4. Schematic representation of MAPK signaling to the translational machinery. The Ras/ERK (green) and p38MAPK (champagne) pathways impinge at different levels on the translational machinery. Although Ras/ ERK signaling stimulates the activity of both RSK (green) and MNK (orange), the latter is also responsive to agonists of the p38MAPK pathway. MNK interacts with eIF4G and on activation phosphorylates eIF4E (orange) at Ser209, a site that increases its oncogenic potential and facilitates the translation of specific mRNAs. Following stimulation of the Ras/ERK pathway, activated RSK phosphorylates rpS6, eIF4B, and eEF2K (green), which are important translational regulators. RSK also participates in the regulation of mTORC1 by inhibiting TSC2 (red) and Deptor (yellow), which are negative regulators of mTORC1. ERK and RSK regulate LKB1-dependent (purple) and -independent phosphorylation of Raptor (pink), resulting in increased mTORC1 signaling. ERK and RSK also collaborate in the regulation of ribosome biogenesis by promoting TIF-1A phosphorylation (green). $\mathrm{T}$ bars represent inhibitory signals, whereas arrows indicate stimulatory signals. Abbreviations and detailed explanations are provided in the text.

(MNK1a and $\mathrm{b}$, and MNK2a and $\mathrm{b}$ ), which are generated by alternative splicing. MNK1a and MNK2a have long $\mathrm{C}$ termini harboring MAPKbinding motifs and show predominantly cytoplasmic localization, whereas MNK1b and MNK2b, which contain short carboxyl termini, are equally distributed between the nucleus and cytoplasm (reviewed by Buxade et al. 2008). In most cell lines, the basal activity of MNK2a is high, which is thought to be a consequence of its ability to sustainably associate with activated ERK (reviewed by Buxade et al. 2008). Con- versely, MNK1a has a low basal activity and it is activated by ERK and p38MAPK in response to stimuli such as growth factors and phorbol esters or cytokines and environmental stress, respectively (Scheper et al. 2001; Wang et al. 2001a). MNK1b exhibits high basal activity, whereas MNK2b, which is the only MNK variant that lacks the MAPK-binding domain, has a very low basal activity (reviewed by Buxade et al. 2008).

MNKs are recruited to eIF4E through association with the carboxy-terminal part of eIF4G, 
P.P. Roux and I. Topisirovic

via a polybasic region located in their amino termini (Pyronnet et al. 1999). Phosphorylation of eIF4E appears to be restricted to metazoans as yeast lack MNK orthologs and a MNK interaction domain in eIF4G. Although initial genetic studies in Drosophila revealed that the phosphorylation of eIF4E is required for normal development, growth, and viability (Lachance et al. 2002), MNK1/2 double knockout (DKO) mice, and mice in which wild-type eIF4E was replaced with a nonphosphorylatable mutant, do not exhibit any conspicuous phenotype (Ueda et al. 2004; Furic et al. 2010). Nonetheless, the phosphorylation of eIF4E appears to be critical for its tumorigenic activity, inasmuch as the nonphosphorylatable mutant of eIF4E exhibits dramatically lower oncogenic potential in vivo and in vitro as compared to wild-type (Topisirovic et al. 2004; Wendel et al. 2007).

The effects of eIF4E phosphorylation on cap-dependent translation are still poorly understood. Because MNKs are recruited to eIF4E via eIF4G (Pyronnet et al. 1999), it is most likely that the phosphorylation of eIF4E occurs during or shortly after the assembly of the eIF4F complex on the $5^{\prime}$-mRNA cap (Fig. 3B). Because Ser209 is located in the proximity of the entrance of the cap-binding pocket of eIF4E, it is plausible that the phosphorylation status of eIF4E alters its cap-binding activity (Topisirovic et al. 2011). It was initially predicted that a salt bridge between the phosphate group of Ser209 and Lys159, forms a "clamp" that stabilizes the eIF4E:5'mRNA cap complex (Marcotrigiano et al. 1997; Matsuo et al. 1997). However, subsequent studies revealed that the phosphorylation of eIF4E reduces its affinity for the cap (Scheper et al. 2002; Slepenkov et al. 2006). Depending on the experimental conditions, eIF4E phosphorylation was shown to correlate with increased (Kaspar et al. 1990; Manzella et al. 1991; Walsh and Mohr 2004; Worch et al. 2004) or decreased global translation rates (Knauf et al. 2001; Morley and Naegele 2002; Naegele and Morley 2004). In addition to the variable effects on global translation, it was shown that the phosphorylation of eIF4E selectively affects translation of a subset of mRNAs, such as Mcl-1 (Wendel et al. 2007). Indeed, a genome-wide comparison of translational activity observed in wild-type mouse embryonic fibroblasts and their counterparts in which wildtype eIF4E was replaced by the nonphosphorylatable mutant, revealed that the phosphorylation status of eIF4E selectively affects translation of a subset of mRNAs including those encoding proteins that play roles in inflammation (e.g., $\mathrm{Ccl} 2$ and Ccl7) and tumor progression (e.g., MMP3 and MMP9) (Furic et al. 2010). These findings suggest an intriguing possibility that phospho-eIF4E modulates the inflammatory response and stimulates tumorigenesis by selectively up-regulating translation of mRNAs that encode proteins critical for these processes.

\section{RSKs}

In addition to being involved in the upstream regulation of mTORC1, several studies have shown a significant role for RSKs in various stages of translational control (Fig. 4). The RSK family is comprised of four Ser/Thr kinases (RSK1-4) that are directly activated by ERK1/ 2-mediated phosphorylation (reviewed by Carriere et al. 2008b). RSK family members exist in all vertebrate species and not so distant RSK orthologs have been identified in Drosophila and C. elegans. All RSK isoforms are expressed at relatively high levels during development and in adult tissues, with the exception of RSK4, which is more abundant during embryogenesis (Zeniou et al. 2002). A notable structural feature of the RSK family came about during evolution, when the genes for two distinct protein kinases fused, generating a single kinase capable of receiving an upstream activating signal from ERK1/2 to the RSK carboxy-terminal kinase domain (CTKD), and transmitting, with high efficiency and fidelity, an activating input to the RSK N-terminal kinase domain (NTKD). Both the NTKD and CTKD are distinct and functional (Jones et al. 1988; Fisher and Blenis 1996), but only the NTKD has thus far been implicated in the phosphorylation of exogenous substrates. This domain belongs to the AGC family of protein kinases, which also includes AKT, PKC, and S6Ks. These kinases phosphorylate very similar consensus sequences and, 
Signaling to the Translational Machinery

consistent with this, several bona fide RSK substrates were also shown to be targeted by AKT, PKC, and/or S6Ks.

The first clue suggesting that RSK may be involved in translational control came 25 years ago when it was identified as an rpS6 kinase in maturating Xenopus laevis oocytes (Erikson and Maller 1985, 1986). A subsequent study showed that activated RSK translocates to polysomes and stimulates the phosphorylation of several ribosome-associated proteins (Angenstein et al. 1998). With the use of rapamycin, the S6Ks were later found to be the predominant rpS6 kinases operating in somatic cells (Chung et al. 1992). Studies from S6K1/2knockout mice confirmed these findings but also showed that there was residual MEK1/ 2-dependent phosphorylation at Ser235/236 (Pende et al. 2004). In accordance with this observation, RSK was shown to specifically phosphorylate rpS6 on Ser235/236 in vitro and in cells in response to agonists of the MAPK pathway (Roux et al. 2007). RSK-mediated phosphorylation of rpS6 correlates with eIF4F complex assembly and cap-dependent translation, suggesting that RSK provides an mTOR/S6Kindependent input linking MAPK signaling to the regulation of translation initiation.

It is now understood that the Ras/MAPK pathway impinges on the PI3K/mTOR pathway at various steps to regulate translation. Aside from its role upstream of mTORC1, RSK phosphorylates additional components of the translational machinery, such as eIF4B in vitro and in vivo (Shahbazian et al. 2006). eIF4B stimulates the RNA-helicase activity of eIF4A (Rozen et al. 1990) and eIF4B phosphorylation was found to promote its interaction with eIF3 ( $\mathrm{Holz}$ et al. 2005; Shahbazian et al. 2006). This interaction correlates with increased translation rates (Shahbazian et al. 2006) and also agrees with the finding that phosphorylated eIF4B stimulates cap-dependent translation in vivo ( Holz et al. 2005). As indicated above, S6Ks also regulate eIF4B phosphorylation, which may explain the biphasic pattern of eIF4B phosphorylation observed in response to certain mitogenic cues.

RSK might also regulate translation through the phosphorylation of GSK3 $\beta$ (Sutherland et al.
1993). As with AKT and S6Ks, RSK-mediated phosphorylation of GSK3 $\beta$ on Ser9 inhibits its kinase activity and thereby releases the inhibition of eIF2B (Cohen and Frame 2001). In collaboration with ERK1/2, RSK2 was shown to participate in rRNA synthesis and cell growth. On serum stimulation, RSK2 phosphorylates a residue important for the function of TIF-1A, a transcription initiation factor required for RNA Pol I activity and rRNA transcription (Zhao et al. 2003). Finally, RSKwas also shown to phosphorylate eEF2 kinase (Wang et al. 2001a), thereby underscoring the involvement of RSK at multiple levels of the pathway that leads to protein synthesis. Thus, RSK activation seems to coordinate crucial processes that are associated with the proper regulation of gene expression and protein synthesis.

\section{FUTURE PERSPECTIVES}

Over the past two decades, significant progress has been made in understanding how translation is modulated by signaling pathways in response to various extracellular stimuli and intracellular cues. Notwithstanding the large body of recently garnered data, in particular those uncovering the molecular mechanisms that underlie the effects of MAPK, TOR (this article), and eIF2 $\alpha$-kinases (Benham 2012) on translation, several outstanding issues await to be addressed. For instance, it has been known for more than a decade that rapamycin suppresses translation of $5^{\prime}$-TOP mRNAs (Jefferies et al. 1994). How mTORC1 stimulates translation of these transcripts is still unknown, however. Moreover, emerging data suggest that mTOR and MAPK act as pivotal regulators of energy metabolism (Shaw and Cantley 2006; Howell and Manning 2011). Protein synthesis is the most energy consuming process in the cell (Buttgereit and Brand 1995), which begs the question of whether mTOR and MAPK act as central nodes of the cellular networks that coordinate changes in the translatome and metabolome by orchestrating the activity of cellular factors involved in their respective processes. Finally, several signaling pathways other than MAPK, TOR, and eIF2 $\alpha$-kinases (e.g., Pak2, 
P.P. Roux and I. Topisirovic

GSK3, Cdk11, and CK2) have been implicated in the phosphorylation of the components of the translational apparatus and auxiliary factors (Table 1), but their physiological role in translational control is still largely unknown. In spite of these issues, there are good reasons to be optimistic as we enter a new era of research in signaling to translational machinery. Recent advances in pharmacological tools (e.g., compounds that specifically and potently target signaling to translational machinery such as active-site mTOR inhibitors [Malina et al. 2012]), and advancements in the technologies that enable monitoring of changes in the phosphoproteome (e.g., quantitative mass spectrometry), translatome (e.g., ribosome profiling/ RNA-seq [Lasko 2012]) on a genome-wide scale will undoubtedly facilitate efforts to establish the role of signaling pathways in translational control in homeostasis and disease.

Table 1. Phosphorylation sites in mammalian translation factors and associated proteins, regulatory kinases, and functional consequences of the phosphorylation

\begin{tabular}{|c|c|c|}
\hline Protein & Phosphorylation sites ${ }^{\mathrm{a}}$ (major kinase) & Function and references ${ }^{b}$ \\
\hline \multirow[t]{3}{*}{ 4E-BP1 } & Thr37, ${ }^{1}$ Thr $46^{1}$ (mTORC1) ${ }^{2}$ & Priming sites ${ }^{3-5}$ \\
\hline & $\begin{array}{l}\text { Ser65 }^{1}(\mathrm{mTORC} 1){ }^{2} \mathrm{Thr}^{1} 0^{1} \\
\quad(\mathrm{mTORC} 1 ? / \mathrm{CDK} 1 ?)\end{array}$ & Dissociation from eIF $4 \mathrm{E}^{3-5}$ \\
\hline & $\begin{array}{l}\text { Ser84 }{ }^{1}(?), \operatorname{Ser} 101^{6}(?), \operatorname{Ser} 112^{7} \\
\quad(\mathrm{CDK} ?)\end{array}$ & Unknown function \\
\hline \multirow[t]{2}{*}{$4 \mathrm{E}-\mathrm{BP} 2$} & Thr $37^{8}, \operatorname{Thr}^{2} 6^{8}$ (mTORC1) & $\begin{array}{l}\text { Priming sites (by analogy with } \\
\text { 4E-BP1) }\end{array}$ \\
\hline & $\begin{array}{l}\text { Ser65 (mTORC1), Thr70 } \\
\quad(? \mathrm{mTORC} 1 / \text { ?CDK1) }\end{array}$ & Dissociation from eIF4E (by analogy with 4E-BP1) \\
\hline \multirow[t]{2}{*}{ eIF4E } & Ser $209^{9}(\mathrm{MNK} 1 / 2)^{10}$ & Unknown function $^{10,11}$ \\
\hline & & $\begin{array}{l}\text { Increases oncogenic activity and promotes } \\
\text { translation of a subset of mRNAs (e.g., Mcl-1, } \\
\text { MMPs, CCLs) }\end{array}$ \\
\hline \multirow[t]{3}{*}{ eIF4GI } & Ser1186 (PKC $\alpha)^{13}$ & Modulates MNK binding ${ }^{13}$ \\
\hline & $\begin{array}{l}\text { Ser } 1108, \text { Ser } 1148, \text { Ser } 1192 \\
\quad(\mathrm{mTORC} 1)^{14}\end{array}$ & $\begin{array}{l}\text { Stimulation of translation of mRNAs } \\
\text { containing upstream open reading frame } \\
(\mathrm{uORF})^{15}(?)\end{array}$ \\
\hline & Ser896 (Pak2) ${ }^{16}$ & Inhibition of cap-dependent translation ${ }^{16}$ \\
\hline eIF2 $\alpha$ & $\begin{array}{l}\text { Ser51 } \\
\text { reviewed in Ref. } 18 \text { and see Pavitt } \\
\text { and Ron }(2012)\end{array}$ & $\begin{array}{l}\text { Stabilizes the eIF2/GDP/eIF2B complex, } \\
\text { thus preventing recycling of eIF2 } \\
\text { (reviewed in Ref. } 18 \text { and see Pavitt } \\
\text { and Ron 2012) }\end{array}$ \\
\hline \multirow[t]{2}{*}{$\mathrm{rpS6}$} & Ser $235^{19}$ and Ser $236^{8}\left(\mathrm{~S} 6 \mathrm{~K} 1 / 2{ }^{8}\right.$ & Unknown function ${ }^{20-23}$ \\
\hline & $\begin{array}{l}\left.\mathrm{RSK}^{20}\right), \text { Ser } 240,{ }^{8} \text { Ser } 244,{ }^{8} \text { and } \\
\operatorname{Ser} 247^{8}(\mathrm{~S} 6 \mathrm{~K} 1 / 2)^{8}\end{array}$ & $\begin{array}{l}\text { Global translation rates increased in MEFs } \\
\text { expressing a nonphosphorylatable form } \\
\text { of rpS6 }\end{array}$ \\
\hline PDCD4 & Ser67, Ser457 (S6K1/2; AKT) ${ }^{25,26}$ & $\begin{array}{l}\text { Degradation by the ubiquitin-proteasome } \\
\text { system and subsequent activation } \\
\text { of eIF } 4 \mathrm{~A}^{25,26}\end{array}$ \\
\hline eIF4B & $\begin{array}{l}\text { Ser406(?), }{ }^{27} \operatorname{Ser} 422\left(\mathrm{~S} 6 \mathrm{~K} 1 / 2,{ }^{28} \mathrm{AKT}^{27}\right. \\
\left.\quad \mathrm{RSK}^{29}\right)\end{array}$ & Increases binding to eIF3 ${ }^{29,30}$ \\
\hline eIF4H & $\begin{array}{l}\text { Tyr12, } \\
\text { (?) }\end{array}$ & ? \\
\hline
\end{tabular}


Table 1. Continued

\begin{tabular}{|c|c|c|}
\hline Protein & Phosphorylation sites ${ }^{\mathrm{a}}$ (major kinase) & Function and references ${ }^{b}$ \\
\hline \multirow[t]{3}{*}{$\mathrm{eIF} 2 \mathrm{~B} \varepsilon$} & Ser540 $(\mathrm{GSK} 3)^{32}$ & Inhibits recycling of eIF2 ${ }^{32}$ \\
\hline & Ser544 (DYRK) $)^{33}$ & Priming site for $\mathrm{GSK} 3^{33}$ \\
\hline & Ser717/718 (CK2) $)^{34}$ & Facilitates eIF2 binding ${ }^{34}$ \\
\hline \multirow{6}{*}{$\begin{array}{l}\text { eIF3 }(29 \\
\text { phosphosites })^{35}\end{array}$} & eIF3b: Ser83, ${ }^{36}$ Ser85, ${ }^{36} \operatorname{Ser} 125^{36}(?)$ & $?$ \\
\hline & $\begin{array}{l}\text { eIF3c: Ser39, }{ }^{37} \text { Ser166, }{ }^{36} \text { Thr524, } \\
\quad \text { Ser909 } \\
\text { (?) }\end{array}$ & ? \\
\hline & eIF3f: Ser46, Thr119 (CDK11) $)^{39,40}$ & $\begin{array}{l}\text { Regulation of protein synthesis } \\
\text { and apoptosis } 39,40\end{array}$ \\
\hline & eIF3g: Thr41, ${ }^{41}$ Ser42 $2^{41}(?)$ & $?$ \\
\hline & eIF3h: Ser $183^{42}(?)$ & Increased oncogenic activity ${ }^{42}$ \\
\hline & eIF3i: Tyr445 31 (?) & ? \\
\hline eIF1 & $\operatorname{Tyr} 30^{31}(?)$ & $?$ \\
\hline eIF5 & Ser389, Ser390 (CK2) $)^{43}$ & Promotes cell cycle progression ${ }^{43}$ \\
\hline eIF5B & $\begin{array}{c}\text { Ser } 107,{ }^{36} \operatorname{Ser} 113,{ }^{36} \mathrm{~S} 135,{ }^{36} \mathrm{~S} 137,,^{38} \\
\mathrm{~S} 164,{ }^{36} \mathrm{~S} 182,{ }^{36} \mathrm{~S} 183,{ }^{38} \mathrm{~S} 186,{ }^{36} \\
\mathrm{~S} 190,{ }^{36} \mathrm{~S} 214,{ }^{41} \mathrm{~S} 1168^{36}(?)\end{array}$ & $?$ \\
\hline eIF6 & Ser235 (PKCßII $)^{44}$ & $\begin{array}{l}\text { Dissociation of eIF6 from the } 60 \mathrm{~S} \text {; } \\
80 \text { S assembly }^{44}\end{array}$ \\
\hline \multirow[t]{3}{*}{ eEF1A } & Thr431 (PKC $\delta)^{45}$ & Activation $(?)^{45}$ \\
\hline & Ser51 (PKC $\beta \mathrm{I})^{46}$ & $?$ \\
\hline & Ser300 (T $\beta R-I)^{47}$ & Inhibition of mRNA translation $^{47}$ \\
\hline eEF2 & Thr56 (eEF2K) ${ }^{48}$ & Inhibits binding to the ribosome $e^{49}$ \\
\hline \multirow[t]{5}{*}{ eEF2K } & Ser78 $(\mathrm{mTOR} ?)^{50}$ & Inhibits CaM binding ${ }^{50}$ \\
\hline & Ser359 $(\mathrm{SAPK} / \mathrm{p} 38 \delta ?)^{51}$ & Inhibition $(?)^{51}$ \\
\hline & Ser366 (S6K1; RSK) $)^{52}$ & Inhibition $^{52}$ \\
\hline & Ser398 (AMPK) $)^{53}$ & Activation $^{53}$ \\
\hline & Ser500 (PKA) $)^{54}$ & Induces $\mathrm{Ca}^{2+}$-independent activity ${ }^{54}$ \\
\hline
\end{tabular}

This table includes selected phospho-acceptor sites identified in large-scale mass-spectrometry-based experiments that await functional characterization (e.g., eIF5B; unknown kinase/function indicated with ?), as well as phosphorylation sites with established role in translational control (e.g., 4E-BPs and eIF2 $\alpha$ ). Further information on the as-yet functionally noncharacterized phosphorylated residues of the components of the translational apparatus can be found on Phosphosite (www.phosphosite.org) or Uniprot (www.uniprot.org) Web sites.

${ }^{a}$ Amino acid numbering is based on human proteins.

${ }^{b}$ References: (1) Fadden et al. (1997); (2) Brunn et al. (1997); (3) Pause et al. (1994); (4) Gingras et al. (1999); (5) Gingras et al. (2001); (6) Wang et al. (2003); (7) Heesom et al. (1998); (8) Wang et al. (2005); (9) Joshi et al. (1995); (10) Waskiewicz et al. (1997); (11) Fukunaga et al. (1997); (12) Furic et al. (2010); (13) Dobrikov et al. (2011); (14) Raught et al. (2000);

(15) Ramirez-Valle et al. (2008); (16) Ling et al. (2005); (17) Kudlicki et al. (1987); (18) Sonenberg and Hinnebusch (2009); (19) Krieg et al. (1988); (20) Roux et al. (2007); (21) Banerjee et al. (1990); (22) Kozma et al. (1990); (23) Pende et al. (2004); (24) Ruvinsky et al. (2005); (25) Dorrello et al. (2006); (26) Palamarchuk et al. (2005); (27) van Gorp et al. (2009); (28) Raught et al. (2004); (29) Shahbazian et al. (2006); (30) Holz et al. (2005); (31) Rush et al. (2005); (32) Welsh et al. (1998); (33) Woods et al. (2001); (34) Wang et al. (2001b); (35) Damoc et al. (2007); (36) Beausoleil et al. (2004); (37) Gevaert et al. (2005); (38) Kim et al. (2005); (39) Shi et al. (2003); (40) Shi et al. (2009); (41) Ballif et al. (2005); (42) Zhang et al. (2008); (43) Homma et al. (2005); (44) Ceci et al. (2003); (45) Kielbassa et al. (1995); (46) Piazzi et al. (2010); (47) Lin et al. (2010); (48) Nairn et al. (1987); (49) Price et al. (1991); (50) Browne et al. (2004); (51) Knebel et al. (2001); (52) Wang et al. (2001a); (53) Horman et al. (2002); (54) Diggle et al. (1998).

Abbreviations: CDK, cyclin-dependent kinase; PKC, protein kinase C; Pak2, p21-activated kinase 2; HRI, heme-regulated eIF2 $\alpha$ kinase; PKR, double-stranded RNA-activated eIF2 $\alpha$ kinase; GCN2, general control nonrepressed eIF2 $\alpha$ kinase; PERK, double-stranded RNA-activated protein kinase-like ER kinase; DYRK, dual-specificity tyrosine phosphorylation-regulated kinase; CK2, protein kinase CK2 (formerly known as casein kinase II); T $\beta R$-I, TGF- $\beta 1$ receptor; eEF2K, eukariotic translation elongation factor 2-kinase; PKA, protein kinase A; SAPK, stress-activated protein kinase. Additional abbreviations are provided in the text. 
P.P. Roux and I. Topisirovic

\section{ACKNOWLEDGMENTS}

We apologize to those authors whose work was not cited because of space constraints. We thank Diane Fingar for invaluable suggestions and comments, Michael Witcher and members of Roux and Topisirovic's laboratories for critical reading of the manuscript, and Valerie Henderson for editing. Topisirovic is supported by grants from the Canadian Institutes of Health Research and Terry Fox Research Institute, whereas Roux is supported by grants from the Canadian Cancer Society Research Institute, the Cancer Research Society, and the Human Frontier Science Program.

\section{REFERENCES \\ * Reference is also in this collection.}

Acosta-Jaquez HA, Keller JA, Foster KG, Ekim B, Soliman GA, Feener EP, Ballif BA, Fingar DC. 2009. Site-specific mTOR phosphorylation promotes mTORC1-mediated signaling and cell growth. Mol Cell Biol 29: 4308-4324.

Angenstein F, Greenough WT, Weiler IJ. 1998. Metabotropic glutamate receptor-initiated translocation of protein kinase p90rsk to polyribosomes: A possible factor regulating synaptic protein synthesis. Proc Natl Acad Sci 95: 15078-15083.

Avruch J, Hara K, Lin Y, Liu M, Long X, Ortiz-Vega S, Yonezawa K. 2006. Insulin and amino-acid regulation of mTOR signaling and kinase activity through the Rheb GTPase. Oncogene 25: 6361-6372.

Ballif BA, Roux PP, Gerber SA, MacKeigan JP, Blenis J, Gygi SP. 2005. Quantitative phosphorylation profiling of the ERK/p90 ribosomal S6 kinase-signaling cassette and its targets, the tuberous sclerosis tumor suppressors. Proc Natl Acad Sci 102: 667-672.

Bandi HR, Ferrari S, Krieg J, Meyer HE, Thomas G. 1993. Identification of $40 \mathrm{~S}$ ribosomal protein S6 phosphorylation sites in Swiss mouse 3T3 fibroblasts stimulated with serum. J Biol Chem 268: 4530-4533.

Banerjee P, Ahmad MF, Grove JR, Kozlosky C, Price DJ, Avruch J. 1990. Molecular structure of a major insulin/ mitogen-activated 70-kDa S6 protein kinase. Proc Natl Acad Sci 87: 8550-8554.

Beausoleil SA, Jedrychowski M, Schwartz D, Elias JE, Villen J, Li J, Cohn MA, Cantley LC, Gygi SP. 2004. Large-scale characterization of HeLa cell nuclear phosphoproteins. Proc Natl Acad Sci 101: 12130-12135.

* Benham AM. 2012. Protein secretion and the endoplasmic reticulum. Cold Spring Harb Perspect Biol doi: 10.1101/ cshperspect.a012872.

Bermek E, Matthaei H. 1971. Interactions between human translocation factor, guanosine triphosphate, and ribosomes. Biochemistry 10: 4906-4912.

Binda M, Peli-Gulli MP, Bonfils G, Panchaud N, Urban J, Sturgill TW, Loewith R, De Virgilio C. 2009. The Vam6
GEF controls TORC1 by activating the EGO complex. Mol Cell 35: 563-573.

* Braun JE, Huntzinger E, Izaurralde E. 2012. A molecular link between miRISCs and deadenylases provides new insight into the mechanism of gene silencing by microRNAs. Cold Spring Harb Perspect Biol doi: 10.1101/ cshperspect.a012328.

Brooks RF. 1977. Continuous protein synthesis is required to maintain the probability of entry into $S$ phase. Cell 12: 311-317.

Browne GJ, Proud CG. 2004. A novel mTOR-regulated phosphorylation site in elongation factor 2 kinase modulates the activity of the kinase and its binding to calmodulin. Mol Cell Biol 24: 2986-2997.

Brugarolas J, Lei K, Hurley RL, Manning BD, Reiling JH, Hafen E, Witters LA, Ellisen LW, Kaelin WG Jr. 2004. Regulation of mTOR function in response to hypoxia by REDD1 and the TSC1/TSC2 tumor suppressor complex. Genes Dev 18: 2893-2904.

Brunn GJ, Hudson CC, Sekulic A, Williams JM, Hosoi H, Houghton PJ, Lawrence JC Jr, Abraham RT. 1997. Phosphorylation of the translational repressor PHAS-I by the mammalian target of rapamycin. Science 277: 99-101.

Buttgereit F, Brand MD. 1995. A hierarchy of ATP-consuming processes in mammalian cells. Biochem J $312(\mathbf{P t} \mathbf{1})$ : 163-167.

Buxade M, Parra-Palau JL, Proud CG. 2008. The Mnks: MAP kinase-interacting kinases (MAP kinase signal-integrating kinases). Front Biosci 13: 5359-5373.

Cantley LC. 2002. The phosphoinositide 3-kinase pathway. Science 296: 1655-1657.

Cargnello M, Roux PP. 2011. Activation and Function of the MAPKs and Their Substrates, the MAPK-Activated Protein Kinases. Microbiol Mol Biol Rev 75: 50-83.

Caron E, Ghosh S, Matsuoka Y, Ashton-Beaucage D, Therrien M, Lemieux S, Perreault C, Roux PP, Kitano H. 2010 A comprehensive map of the mTOR signaling network. Mol Syst Biol 6: 453.

Carriere A, Cargnello M, Julien LA, Gao H, Bonneil E, Thibault P, Roux PP. 2008a. Oncogenic MAPK signaling stimulates mTORC1 activity by promoting RSK-mediated raptor phosphorylation. Curr Biol 18: 1269-1277.

Carriere A, Ray H, Blenis J, Roux PP. 2008b. The RSK factors of activating the Ras/MAPK signaling cascade. Front $B i-$ osci 13: $4258-4275$.

Carriere A, Romeo Y, Acosta-Jaquez HA, Moreau J, Bonneil E, Thibault P, Fingar DC, Roux PP. 2011. ERK1/2 phosphorylate Raptor to promote Ras-dependent activation of mTOR complex 1 (mTORC1). J Biol Chem 286: 567-577.

Ceci M, Gaviraghi C, Gorrini C, Sala LA, Offenhauser N, Marchisio PC, Biffo S. 2003. Release of eIF6 (p27BBP) from the $60 \mathrm{~S}$ subunit allows $80 \mathrm{~S}$ ribosome assembly. $\mathrm{Na}$ ture 426: 579-584

Chen J, Zheng XF, Brown EJ, Schreiber SL. 1995. Identification of an 11-kDa FKBP12-rapamycin-binding domain within the 289-kDa FKBP12-rapamycin-associated protein and characterization of a critical serine residue. Proc Natl Acad Sci 92: 4947-4951. 
Chen Z, Gibson TB, Robinson F, Silvestro L, Pearson G, Xu B, Wright A, Vanderbilt C, Cobb MH. 2001. MAP kinases. Chem Rev 101: 2449-2476.

Choo AY, Yoon SO, Kim SG, Roux PP, Blenis J. 2008. Rapamycin differentially inhibits S6Ks and 4E-BP1 to mediate cell-type-specific repression of mRNA translation. Proc Natl Acad Sci 105: 17414-17419.

Chung J, Kuo CJ, Crabtree GR, Blenis J. 1992. RapamycinFKBP specifically blocks growth-dependent activation of and signaling by the $70 \mathrm{kd} \mathrm{S6}$ protein kinases. Cell 69: $1227-1236$

Cohen P, Frame S. 2001. The renaissance of GSK3. Nat Rev Mol Cell Biol 2: 769-776.

Colina R, Costa-Mattioli M, Dowling RJ, Jaramillo M, Tai LH, Breitbach CJ, Martineau Y, Larsson O, Rong L, Svitkin YV, et al. 2008. Translational control of the innate immune response through IRF-7. Nature 452: 323-328.

Corradetti MN, Inoki K, Bardeesy N, DePinho RA, Guan KL. 2004. Regulation of the TSC pathway by LKB1: Evidence of a molecular link between tuberous sclerosis complex and Peutz-Jeghers syndrome. Genes Dev 18: 1533-1538.

De Benedetti A, Graff JR. 2004. eIF-4E expression and its role in malignancies and metastases. Oncogene 23: 3189-3199.

DeYoung MP, Horak P, Sofer A, Sgroi D, Ellisen LW. 2008. Hypoxia regulates TSC1/2-mTOR signaling and tumor suppression through REDD1-mediated 14-3-3 shuttling. Genes Dev 22: 239-251.

Diggle TA, Redpath NT, Heesom KJ, Denton RM. 1998. Regulation of protein-synthesis elongation-factor-2 kinase by cAMP in adipocytes. Biochem J 336: 525-529.

Dobrikov M, Dobrikova E, Shveygert M, Gromeier M. 2011 Phosphorylation of eukaryotic translation initiation factor 4G1 (eIF4G1) by protein kinase $\mathrm{C} \alpha$ regulates eIF4G1 binding to Mnk1. Mol Cell Biol 31: 2947-2959.

Dorrello NV, Peschiaroli A, Guardavaccaro D, Colburn NH, Sherman NE, Pagano M. 2006. S6K1- and BTRCP-mediated degradation of PDCD4 promotes protein translation and cell growth. Science 314: 467-471.

Dowling RJ, Zakikhani M, Fantus IG, Pollak M, Sonenberg N. 2007. Metformin inhibits mammalian target of rapamycin-dependent translation initiation in breast cancer cells. Cancer Res 67: 10804-10812.

Dowling RJ, Topisirovic I, Alain T, Bidinosti M, Fonseca BD, Petroulakis E, Wang X, Larsson O, Selvaraj A, Liu Y, et al. 2010a. mTORC1-mediated cell proliferation, but not cell growth, controlled by the 4E-BPs. Science 328: $1172-$ 1176.

Dowling RJ, Topisirovic I, Fonseca BD, Sonenberg N. 2010b. Dissecting the role of mTOR: Lessons from mTOR inhibitors. Biochim Biophys Acta 1804: 433-439.

Duran A, Amanchy R, Linares JF, Joshi J, Abu-Baker S, Porollo A, Hansen M, Moscat J, Diaz-Meco MT. 2011. p62 is a key regulator of nutrient sensing in the mTORC1 pathway. Mol Cell 44: 134-146.

Ekim B, Magnuson B, Acosta-Jaquez HA, Keller JA, Feener EP, Fingar DC. 2011. mTOR kinase domain phosphorylation promotes mTORC1 signaling, cell growth, and cell cycle progression. Mol Cell Biol 31: 2787-2801.
Ellisen LW, Ramsayer KD, Johannessen CM, Yang A, Beppu H, Minda K, Oliner JD, McKeon F, Haber DA. 2002. REDD1, a developmentally regulated transcriptional target of p63 and p53, links p63 to regulation of reactive oxygen species. Mol Cell 10: 995-1005.

Engelman JA, Luo J, Cantley LC. 2006. The evolution of phosphatidylinositol 3-kinases as regulators of growth and metabolism. Nat Rev Genet 7: 606-619.

Erikson E, Maller JL. 1985. A protein kinase from Xenopus eggs specific for ribosomal protein S6. Proc Natl Acad Sci 82: $742-746$.

Erikson E, Maller JL. 1986. Purification and characterization of a protein kinase from Xenopus eggs highly specific for ribosomal protein S6. J Biol Chem 261: 350-355.

Fadden P, Haystead TA, Lawrence JC Jr. 1997. Identification of phosphorylation sites in the translational regulator PHAS-I that are controlled by insulin and rapamycin in rat adipocytes. J Biol Chem 272: 10240-10247.

Fenton TR, Gout IT. 2011. Functions and regulation of the 70kDa ribosomal S6 kinases. Int J Biochem Cell Biol 43: 47-59.

Ferrari S, Bandi HR, Hofsteenge J, Bussian BM, Thomas G. 1991. Mitogen-activated 70K S6 kinase. Identification of in vitro $40 \mathrm{~S}$ ribosomal S6 phosphorylation sites. J Biol Chem 266: 22770-22775.

Fingar DC, Blenis J. 2004. Target of rapamycin (TOR): An integrator of nutrient and growth factor signals and coordinator of cell growth and cell cycle progression. Oncogene 23: 3151-3171.

Fisher TL, Blenis J. 1996. Evidence for two catalytically active kinase domains in pp90rsk. Mol Cell Biol 16: 1212-1219.

Fonseca BD, Smith EM, Lee VH, MacKintosh C, Proud CG. 2007. PRAS40 is a target for mammalian target of rapamycin complex 1 and is required for signaling downstream of this complex. J Biol Chem 282: 24514-24524.

Foster KG, Acosta-Jaquez HA, Romeo Y, Ekim B, Soliman GA, Carriere A, Roux PP, Ballif BA, Fingar DC. 2010. Regulation of mTOR complex 1 (mTORC1) by raptor Ser863 and multisite phosphorylation. J Biol Chem 285: 80-94.

Frias MA, Thoreen CC, Jaffe JD, Schroder W, Sculley T, Carr SA, Sabatini DM. 2006. mSin 1 is necessary for Akt/PKB phosphorylation, and its isoforms define three distinct mTORC2s. Curr Biol 16: 1865-1870.

Fukunaga R, Hunter T. 1997. MNK1, a new MAP kinaseactivate protein kinase, isolated by a novel expression screening method for identifying protein kinase substrates. EMBO J 16: 1921-1997.

Furic L, Rong L, Larsson O, Koumakpayi IH, Yoshida K, Brueschke A, Petroulakis E, Robichaud N, Pollak M, Gaboury LA, et al. 2010. eIF4E phosphorylation promotes tumorigenesis and is associated with prostate cancer progression. Proc Natl Acad Sci 107: 14134-14139.

Gaestel M. 2006. MAPKAP kinases-MKs—-two's company, three's a crowd. Nat Rev Mol Cell Biol 7: 120-130.

Gaestel M. 2008. Specificity of signaling from MAPKs to MAPKAPKs: Kinases' tango nuevo. Front Biosci 13: 6050-6059.

Garami A, Zwartkruis FJ, Nobukuni T, Joaquin M, Roccio M, Stocker H, Kozma SC, Hafen E, Bos JL, Thomas G. 2003. Insulin activation of Rheb, a mediator of mTOR/ 
P.P. Roux and I. Topisirovic

S6K/4E-BP signaling, is inhibited by TSC1 and 2. Mol Cell 11: 1457-1466.

Garcia-Martinez JM, Alessi DR. 2008. mTOR complex 2 (mTORC2) controls hydrophobic motif phosphorylation and activation of serum- and glucocorticoid-induced protein kinase 1 (SGK1). Biochem J 416: 375-385.

Gevaert K, Staes A, Van Damme J, De Groot S, Hugelier K, Demol H, Martens L, Goethals M, Vandekerckhove J. 2005. Global phosphoproteome analysis on human HepG2 hepatocytes using reversed-phase diagonal LC. Proteomics 5: 3589-3599.

Gingras AC, Gygi SP, Raught B, Polakiewicz RD, Abraham RT, Hoekstra MF, Aebersold R, Sonenberg N. 1999a. Regulation of 4E-BP1 phosphorylation: A novel two-step mechanism. Genes Dev 13: 1422-1437.

Gingras AC, Raught B, Sonenberg N. 1999b. eIF4 initiation factors: Effectors of mRNA recruitment to ribosomes and regulators of translation. Annu Rev Biochem 68: 913-963.

Gingras AC, Raught B, Gygi SP, Niedzwiecka A, Miron M, Burley SK, Polakiewicz RD, Wyslouch-Cieszynska A, Aebersold R, Sonenberg N. 2001. Hierarchical phosphorylation of the translation inhibitor 4E-BP1. Genes Dev 15: $2852-2864$.

Goke A, Goke R, Knolle A, Trusheim H, Schmidt H, Wilmen A, Carmody R, Goke B, Chen YH. 2002. DUG is a novel homologue of translation initiation factor $4 \mathrm{G}$ that binds eIF4A. Biochem Biophys Res Commun 297: 78-82.

Gout I, Minami T, Hara K, Tsujishita Y, Filonenko V, Waterfield MD, Yonezawa K. 1998. Molecular cloning and characterization of a novel p70 S6 kinase, p70 S6 kinase beta containing a proline-rich region. J Biol Chem 273: 30061-30064.

Graff JR, Zimmer SG. 2003. Translational control and metastatic progression: Enhanced activity of the mRNA capbinding protein eIF-4E selectively enhances translation of metastasis-related mRNAs. Clin Exp Metastasis 20: 265273.

Graff JR, Konicek BW, Carter JH, Marcusson EG. 2008. Targeting the eukaryotic translation initiation factor $4 \mathrm{E}$ for cancer therapy. Cancer Res 68: 631-634.

Greenbaum D, Luscombe NM, Jansen R, Qian J, Gerstein M. 2001. Interrelating different types of genomic data, from proteome to secretome: 'oming in on function. Genome Res 11: 1463-1468.

Grifo JA, Abramson RD, Satler CA, Merrick WC. 1984. RNA-stimulated ATPase activity of eukaryotic initiation factors. J Biol Chem 259: 8648-8654.

Grove JR, Banerjee P, Balasubramanyam A, Coffer PJ, Price DJ, Avruch J, Woodgett JR. 1991. Cloning and expression of two human p70 S6 kinase polypeptides differing only at their amino termini. Mol Cell Biol 11: 5541-5550.

Guertin DA, Sabatini DM. 2007. Defining the role of mTOR in cancer. Cancer Cell 12: 9-22.

Guertin DA, Sabatini DM. 2009. The pharmacology of mTOR inhibition. Sci Signal 2: e24.

Gwinn DM, Shackelford DB, Egan DF, Mihaylova MM, Mery A, Vasquez DS, Turk BE, Shaw RJ. 2008. AMPK phosphorylation of raptor mediates a metabolic checkpoint. Mol Cell 30: 214-226.
Hara K, Yonezawa K, Weng QP, Kozlowski MT, Belham C, Avruch J. 1998. Amino acid sufficiency and mTOR regulate p70 S6 kinase and eIF-4E BP1 through a common effector mechanism. J Biol Chem 273: 14484-14494.

Hay N, Sonenberg N. 2004. Upstream and downstream of mTOR. Genes Dev 18: 1926-1945.

Heesom KJ, Avison MB, Diggle TA, Denton RM. 1998. Insulin-stimulated kinase from rat fat cells that phosphorylates initiation factor $4 \mathrm{E}$-binding protein 1 on the rapamycin-insensitive site (serine-111). Biochem J 336 (Pt 1): 39-48.

Holz MK, Ballif BA, Gygi SP, Blenis J. 2005. mTOR and S6K1 mediate assembly of the translation preinitiation complex through dynamic protein interchange and ordered phosphorylation events. Cell 123: 569-580.

Homma MK, Wada I, Suzuki T, Yamaki J, Krebs EG, Homma Y. 2005. CK2 phosphorylation of eukaryotic translation initiation factor 5 potentiates cell cycle progression. Proc Natl Acad Sci 102: 15688-15693.

Horman S, Browne G, Krause U, Patel J, Vertommen D, Bertrand L, Lavoinne A, Hue L, Proud C, Rider M. 2002. Activation of AMP-activated protein kinase leads to the phosphorylation of elongation factor 2 and an inhibition of protein synthesis. Curr Biol 12: 1419-1423.

Howell JJ, Manning BD. 2011. mTOR couples cellular nutrient sensing to organismal metabolic homeostasis. Trends Endocrinol Metab 22: 94-102.

Inoki K, Li Y, Xu T, Guan KL. 2003. Rheb GTPase is a direct target of TSC2 GAP activity and regulates mTOR signaling. Genes Dev 17: 1829-1834.

Jacinto E, Facchinetti V, Liu D, Soto N, Wei S, Jung SY, Huang Q, Qin J, Su B. 2006. SIN1/MIP1 maintains rictor-mTOR complex integrity and regulates Akt phosphorylation and substrate specificity. Cell 127: 125-137.

Jackson RJ, Hellen CU, Pestova TV. 2010. The mechanism of eukaryotic translation initiation and principles of its regulation. Nat Rev Mol Cell Biol 11: 113-127.

Jefferies HB, Reinhard C, Kozma SC, Thomas G. 1994. Rapamycin selectively represses translation of the "polypyrimidine tract" mRNA family. Proc Natl Acad Sci 91: $4441-4445$.

Johannessen CM, Reczek EE, James MF, Brems H, Legius E, Cichowski K. 2005. The NF1 tumor suppressor critically regulates TSC2 and mTOR. Proc Natl Acad Sci 102: 8573-8578.

Johannessen CM, Johnson BW, Williams SM, Chan AW, Reczek EE, Lynch RC, Rioth MJ, McClatchey A, Ryeom S, Cichowski K. 2008. TORC1 is essential for NF1-associated malignancies. Curr Biol 18: 56-62.

Jones SW, Erikson E, Blenis J, Maller JL, Erikson RL. 1988. A Xenopus ribosomal protein S6 kinase has two apparent kinase domains that are each similar to distinct protein kinases. Proc Natl Acad Sci 85: 3377-3381.

Joshi B, Cai AL, Keiper BD, Minich WB, Mendez R, Beach CM, Stepinski J, Stolarski R, Darzynkiewicz E, Rhoads RE. 1995. Phosphorylation of eukaryotic protein synthesis initiation factor $4 \mathrm{E}$ at Ser-209. J Biol Chem 270: 14597-14603.

Kahn BB, Alquier T, Carling D, Hardie DG. 2005. AMPactivated protein kinase: Ancient energy gauge provides 
clues to modern understanding of metabolism. Cell Metab 1: 15-25.

Kantidakis T, Ramsbottom BA, Birch JL, Dowding SN, White RJ. 2010. mTOR associates with TFIIIC, is found at tRNA and 5S rRNA genes, and targets their repressor Maf1. Proc Natl Acad Sci 107: 11823-11828.

Kaspar RL, Rychlik W, White MW, Rhoads RE, Morris DR. 1990. Simultaneous cytoplasmic redistribution of ribosomal protein L32 mRNA and phosphorylation of eukaryotic initiation factor $4 \mathrm{E}$ after mitogenic stimulation of Swiss 3T3 cells. J Biol Chem 265: 3619-3622.

Kawasome H, Papst P, Webb S, Keller GM, Johnson GL, Gelfand EW, Terada N. 1998. Targeted disruption of p70(s6k) defines its role in protein synthesis and rapamycin sensitivity. Proc Natl Acad Sci 95: 5033-5038.

Kielbassa K, Muller HJ, Meyer HE, Marks F, Gschwendt M. 1995. Protein kinase C delta-specific phosphorylation of the elongation factor eEF-alpha and an eEF-1 alpha peptide at threonine 431. J Biol Chem 270: 6156-6162.

Kim J, Guan KL. 2011. Amino acid signaling in TOR activation. Annu Rev Biochem 80: 1001-1032.

Kim JE, Tannenbaum SR, White FM. 2005. Global phosphoproteome of HT-29 human colon adenocarcinoma cells. J Proteome Res 4: 1339-1346.

Kim E, Goraksha-Hicks P, Li L, Neufeld TP, Guan KL. 2008. Regulation of TORC1 by Rag GTPases in nutrient response. Nat Cell Biol 10: 935-945.

Knauf U, Tschopp C, Gram H. 2001. Negative regulation of protein translation by mitogen-activated protein kinaseinteracting kinases 1 and 2. Mol Cell Biol 21: 5500-5511.

Knebel A, Morrice N, Cohen P. 2001. A novel method to identify protein kinase substrates: eEF2 kinase is phosphorylated and inhibited by SAPK4/p38delta. EMBO J 20: $4360-4369$.

Koromilas AE, Lazaris-Karatzas A, Sonenberg N. 1992. mRNAs containing extensive secondary structure in their $5^{\prime}$ noncoding region translate efficiently in cells overexpressing initiation factor eIF-4E. EMBO J 11: 4153-4158.

Kozma SC, Ferrari S, Bassand P, Siegmann M, Totty N, Thomas G. 1990. Cloning of the mitogen-activated S6 kinase from rat liver reveals an enzyme of the second messenger subfamily. Proc Natl Acad Sci 87: 7365-7369.

Krieg J, Hofsteenge J, Thomas G. 1988. Identification of the $40 \mathrm{~S}$ ribosomal protein $\mathrm{S} 6$ phosphorylation sites induced by cycloheximide. J Biol Chem 263: 11473-11477.

Kudlicki W, Wettenhall RE, Kemp BE, Szyszka R, Kramer G, Hardesty B. 1987. Evidence for a second phosphorylation site on eIF-2 alpha from rabbit reticulocytes. FEBS Lett 215: $16-20$.

Kwiatkowski DJ, Manning BD. 2005. Tuberous sclerosis: a GAP at the crossroads of multiple signaling pathways. Hum Mol Genet 14 (Spec No 2): R251-R258.

Kyriakis JM, Avruch J. 2001. Mammalian mitogen-activated protein kinase signal transduction pathways activated by stress and inflammation. Physiol Rev 81: 807-869.

Lachance PE, Miron M, Raught B, Sonenberg N, Lasko P. 2002. Phosphorylation of eukaryotic translation initiation factor 4E is critical for growth. Mol Cell Biol 22: $1656-1663$.
Lankat-Buttgereit B, Goke R. 2009. The tumour suppressor Pdcd4: Recent advances in the elucidation of function and regulation. Biol Cell 101: 309-317.

Laplante M, Sabatini DM. 2009. mTOR signaling at a glance. J Cell Sci 122 (Pt 20): 3589-3594.

* Lasko P. 2012. mRNA localization and translational control in Drosophila oogenesis. Cold Spring Harb Perspect Biol doi: $10.1101 /$ cshperspect.a012294.

Levy S, Avni D, Hariharan N, Perry RP, Meyuhas O. 1991. Oligopyrimidine tract at the $5^{\prime}$ end of mammalian ribosomal protein mRNAs is required for their translational control. Proc Natl Acad Sci 88: 3319-3323.

Li Y, Wang Y, Kim E, Beemiller P, Wang CY, Swanson J, You M, Guan KL. 2007. Bnip3 mediates the hypoxia-induced inhibition on mammalian target of rapamycin by interacting with Rheb. J Biol Chem 282: 35803-35813.

Lin KW, Yakymovych I, Jia M, Yakymovych M, Souchelnytskyi S. 2010. Phosphorylation of eEF1A1 at Ser300 by TbetaR-I results in inhibition of mRNA translation. Curr Biol 20: 1615-1625.

Ling J, Morley SJ, Traugh JA. 2005. Inhibition of cap-dependent translation via phosphorylation of eIF4G by protein kinase Pak2. EMBO J 24: 4094-4105.

Loreni F, Thomas G, Amaldi F. 2000. Transcription inhibitors stimulate translation of $5^{\prime}$ TOP mRNAs through activation of S6 kinase and the mTOR/FRAP signalling pathway. Eur J Biochem 267: 6594-6601.

Lynch M, Fitzgerald C, Johnston KA, Wang S, Schmidt EV. 2004. Activated eIF4E-binding protein slows G1 progression and blocks transformation by c-myc without inhibiting cell growth. J Biol Chem 279: 3327-3339.

Ma L, Chen Z, Erdjument-Bromage H, Tempst P, Pandolfi PP. 2005. Phosphorylation and functional inactivation of TSC2 by Erk implications for tuberous sclerosis and cancer pathogenesis. Cell 121: 179-193.

Ma XM, Blenis J. 2009. Molecular mechanisms of mTORmediated translational control. Nat Rev Mol Cell Biol 10: 307-318.

Ma XM, Yoon SO, Richardson CJ, Julich K, Blenis J. 2008. SKAR links pre-mRNA splicing to mTOR/S6K1-mediated enhanced translation efficiency of spliced mRNAs. Cell 133: 303-313.

Maehama T, Dixon JE. 1998. The tumor suppressor, PTEN/ MMAC1, dephosphorylates the lipid second messenger, phosphatidylinositol 3,4,5-trisphosphate. J Biol Chem 273: $13375-13378$.

* Malina A, Mills JR, Pelletier J. 2012. Emerging therapeutics targeting mRNA translation. Cold Spring Harb Perspect Biol doi: 10.1101/cshperspect.a012377.

Manning BD, Tee AR, Logsdon MN, Blenis J, Cantley LC. 2002. Identification of the tuberous sclerosis complex-2 tumor suppressor gene product tuberin as a target of the phosphoinositide 3-kinase/akt pathway. Mol Cell 10: $151-162$.

Manzella JM, Rychlik W, Rhoads RE, Hershey JW, Blackshear PJ. 1991. Insulin induction of ornithine decarboxylase. Importance of mRNA secondary structure and phosphorylation of eucaryotic initiation factors eIF-4B and eIF-4E. J Biol Chem 266: 2383-2389.

Marcotrigiano J, Gingras AC, Sonenberg N, Burley SK. 1997. Cocrystal structure of the messenger RNA $5^{\prime}$ cap-binding 
P.P. Roux and I. Topisirovic

protein (eIF4E) bound to 7-methyl-GDP. Cell 89: 951961.

Mathews MB, Sonenberg N, Hershey JWB. 2007. Translational control in biology and medicine. In Translational control in biology and medicine (ed. NS Michael, B Mathews, W John, B Hershey). Cold Spring Harbor Laboratory Press, Cold Spring, NY.

Matsuo H, Li H, McGuire AM, Fletcher CM, Gingras AC, Sonenberg N, Wagner G. 1997. Structure of translation factor eIF4E bound to m7GDP and interaction with $4 \mathrm{E}-$ binding protein. Nat Struct Biol 4: 717-724.

Mayer C, Zhao J, Yuan X, Grummt I. 2004. mTOR-dependent activation of the transcription factor TIF-IA links rRNA synthesis to nutrient availability. Genes Dev 18: 423-434.

Meyuhas O. 2008. Physiological roles of ribosomal protein S6: One of its kind. Int Rev Cell Mol Biol 268: 1-37.

Michels AA, Robitaille AM, Buczynski-Ruchonnet D, Hodroj W, Reina JH, Hall MN, Hernandez N. 2010 mTORC1 directly phosphorylates and regulates human MAF1. Mol Cell Biol 30: 3749-3757.

Miron M, Verdu J, Lachance PE, Birnbaum MJ, Lasko PF Sonenberg N. 2001. The translational inhibitor 4E-BP is an effector of $\mathrm{PI}(3) \mathrm{K} /$ Akt signalling and cell growth in Drosophila. Nat Cell Biol 3: 596-601.

Montagne J, Stewart MJ, Stocker H, Hafen E, Kozma SC, Thomas G. 1999. Drosophila S6 kinase: A regulator of cell size. Science 285: 2126-2129.

Morley SJ, Naegele S. 2002. Phosphorylation of eukaryotic initiation factor (eIF) $4 \mathrm{E}$ is not required for de novo protein synthesis following recovery from hypertonic stress in human kidney cells. J Biol Chem 277: 3285532859.

Naegele S, Morley SJ. 2004. Molecular cross-talk between MEK1/2 and mTOR signaling during recovery of 293 cells from hypertonic stress. J Biol Chem 279: $46023-$ 46034.

Nairn AC, Palfrey HC. 1987. Identification of the major Mr 100000 substrate for calmodulin-dependent protein kinase III in mammalian cells as elongation factor-2. J Biol Chem 262: 17299-17303.

Oh WJ, Jacinto E. 2011. mTOR complex 2 signaling and functions. Cell Cycle 10: 2305-2316.

Oh WJ, Wu CC, Kim SJ, Facchinetti V, Julien LA, Finlan M, Roux PP, Su B, Jacinto E. 2010. mTORC2 can associate with ribosomes to promote cotranslational phosphorylation and stability of nascent Akt polypeptide. EMBO J 29: 3939-3951.

Ohanna M, Sobering AK, Lapointe T, Lorenzo L, Praud C, Petroulakis E, Sonenberg N, Kelly PA, Sotiropoulos A, Pende M. 2005. Atrophy of S6K1(-/-) skeletal muscle cells reveals distinct mTOR effectors for cell cycle and size control. Nat Cell Biol 7: 286-294.

Oshiro N, Takahashi R, Yoshino K, Tanimura K, Nakashima A, Eguchi S, Miyamoto T, Hara K, Takehana K, Avruch J, et al. 2007. The proline-rich Akt substrate of $40 \mathrm{kDa}$ (PRAS40) is a physiological substrate of mammalian target of rapamycin complex 1. J Biol Chem 282: 2032920339.

Palamarchuk A, Efanov A, Maximov V, Aqeilan RI, Croce CM, Pekarsky Y. 2005. Akt phosphorylates and regulates
Pdcd4 tumor suppressor protein. Cancer Res 65: $11282-$ 11286.

Pause A, Belsham GJ, Gingras AC, Donze O, Lin TA, Lawrence JC Jr, Sonenberg N. 1994. Insulin-dependent stimulation of protein synthesis by phosphorylation of a regulator of $5^{\prime}$-cap function. Nature 371: 762-767.

* Pavitt GD, Ron D. 2012. New insights into translational regulation in the endoplasmic reticulum unfolded protein response. Cold Spring Harb Perspect Biol doi: 10.1101/cshperspect.a012278.

Pearce LR, Huang X, Boudeau J, Pawlowski R, Wullschleger S, Deak M, Ibrahim AF, Gourlay R, Magnuson MA, Alessi DR. 2007. Identification of Protor as a novel Rictor-binding component of mTOR complex-2. Biochem J 405: 513-522.

Pearce LR, Komander D, Alessi DR. 2010. The nuts and bolts of AGC protein kinases. Nat Rev Mol Cell Biol 11: 9-22.

Pearson G, Robinson F, Beers Gibson T, Xu BE, Karandikar M, Berman K, Cobb MH. 2001. Mitogen-activated protein (MAP) kinase pathways: Regulation and physiological functions. Endocr Rev 22: 153-183.

Pende M, Um SH, Mieulet V, Sticker M, Goss VL, Mestan J, Mueller M, Fumagalli S, Kozma SC, Thomas G. 2004. S6K1(-/-)/S6K2(-/-) mice exhibit perinatal lethality and rapamycin-sensitive $5^{\prime}$-terminal oligopyrimidine mRNA translation and reveal a mitogen-activated protein kinase-dependent S6 kinase pathway. Mol Cell Biol 24: 3112-3124.

Peterson TR, Laplante M, Thoreen CC, Sancak Y, Kang SA, Kuehl WM, Gray NS, Sabatini DM. 2009. DEPTOR is an mTOR inhibitor frequently overexpressed in multiple myeloma cells and required for their survival. Cell 137: 873-886.

Petroulakis E, Mamane Y, Le Bacquer O, Shahbazian D, Sonenberg N. 2006. mTOR signaling: Implications for cancer and anticancer therapy. Br J Cancer 94: 195-199.

Petroulakis E, Parsyan A, Dowling RJ, LeBacquer O, Martineau Y, Bidinosti M, Larsson O, Alain T, Rong L, Mamane Y, et al. 2009. p53-dependent translational control of senescence and transformation via 4E-BPs. Cancer Cell 16: $439-446$.

Piazzi M, Bavelloni A, Faenza I, Blalock W, Urbani A, D’Aguanno S, Fiume R, Ramazzotti G, Maraldi NM, Cocco L. 2010. eEF1A phosphorylation in the nucleus of insulin-stimulated C2C12 myoblasts: $\operatorname{Ser}(3)$ is a novel substrate for protein kinase C betaI. Mol Cell Proteomics 9: 2719-2728.

Price NT, Redpath NT, Severinov KV, Campbell DG, Russell JM, Proud CG. 1991. Identification of the phosphorylation sites in elongation factor-2 from rabbit reticulocytes. FEBS Lett 282: 253-258.

Pyronnet S, Imataka H, Gingras AC, Fukunaga R, Hunter T, Sonenberg N. 1999. Human eukaryotic translation initiation factor $4 \mathrm{G}$ (eIF4G) recruits mnk1 to phosphorylate eIF4E. EMBO J 18: 270-279.

Rajalingam K, Schreck R, Rapp UR, Albert S. 2007. Ras oncogenes and their downstream targets. Biochim Biophys Acta 1773: 1177-1195.

Ramirez-Valle F, Braunstein S, Zavadil J, Formenti SC, Schneider RJ. 2008. eIF4GI links nutrient sensing by mTOR to cell proliferation and inhibition of autophagy. J Cell Biol 181: 293-307. 
Rapley J, Oshiro N, Ortiz-Vega S, Avruch J. 2011. The mech anism of insulin-stimulated $4 \mathrm{E}-\mathrm{BP}$ protein binding to mammalian target of rapamycin (mTOR) complex 1 and its contribution to mTOR complex 1 signaling. $J$ Biol Chem 286: 38043-38053.

Raught B, Gingras AC, Gygi SP, Imataka H, Morino S, Gradi A, Aebersold R, Sonenberg N. 2000. Serum-stimulated, rapamycin-sensitive phosphorylation sites in the eukaryotic translation initiation factor 4GI. EMBO J 19: 434-444.

Raught B, Peiretti F, Gingras AC, Livingstone M, Shahbazian D, Mayeur GL, Polakiewicz RD, Sonenberg N, Hershey JW. 2004. Phosphorylation of eucaryotic translation initiation factor 4B Ser422 is modulated by S6 kinases. EMBO J 23: 1761-1769.

Richardson CJ, Broenstrup M, Fingar DC, Julich K, Ballif BA, Gygi S, Blenis J. 2004. SKAR is a specific target of S6 kinase 1 in cell growth control. Curr Biol 14: 1540-1549.

Richter-Cook NJ, Dever TE, Hensold JO, Merrick WC. 1998. Purification and characterization of a new eukaryotic protein translation factor. Eukaryotic initiation factor 4H. J Biol Chem 273: 7579-7587.

Rogers GW Jr, Richter NJ, Lima WF, Merrick WC. 2001. Modulation of the helicase activity of eIF4A by eIF4B, eIF4H, and eIF4F. J Biol Chem 276: 30914-30922.

Roux PP, Blenis J. 2004. ERK and p38 MAPK-activated protein kinases: A family of protein kinases with diverse biological functions. Microbiol Mol Biol Rev 68: 320-344.

Roux PP, Ballif BA, Anjum R, Gygi SP, Blenis J. 2004. Tumorpromoting phorbol esters and activated Ras inactivate the tuberous sclerosis tumor suppressor complex via p90 ribosomal S6 kinase. Proc Natl Acad Sci 101: 13489-13494.

Roux PP, Shahbazian D, Vu H, Holz MK, Cohen MS, Taunton J, Sonenberg N, Blenis J. 2007. RAS/ERK signaling promotes site-specific ribosomal protein S6 phosphorylation via RSK and stimulates cap-dependent translation. J Biol Chem 282: 14056-14064.

Rozen F, Edery I, Meerovitch K, Dever TE, Merrick WC, Sonenberg N. 1990. Bidirectional RNA helicase activity of eucaryotic translation initiation factors $4 \mathrm{~A}$ and $4 \mathrm{~F}$. Mol Cell Biol 10: 1134-1144.

Rush J, Moritz A, Lee KA, Guo A, Goss VL, Spek EJ, Zhang H, Zha XM, Polakiewicz RD, Comb MJ. 2005. Immunoaffinity profiling of tyrosine phosphorylation in cancer cells. Nat Biotechnol 23: 94-101.

Ruvinsky I, Sharon N, Lerer T, Cohen H, Stolovich-Rain M, Nir T, Dor Y, Zisman P, Meyuhas O. 2005. Ribosomal protein S6 phosphorylation is a determinant of cell size and glucose homeostasis. Genes Dev 19: 2199-2211.

Sancak Y, Thoreen CC, Peterson TR, Lindquist RA, Kang SA, Spooner E, Carr SA, Sabatini DM. 2007. PRAS40 is an insulin-regulated inhibitor of the mTORC1 protein kinase. Mol Cell 25: 903-915.

Sancak Y, Peterson TR, Shaul YD, Lindquist RA, Thoreen CC, Bar-Peled L, Sabatini DM. 2008. The Rag GTPases bind raptor and mediate amino acid signaling to mTORC1. Science 320: 1496-1501.

Sancak Y, Bar-Peled L, Zoncu R, Markhard AL, Nada S, Sabatini DM. 2010. Ragulator-Rag complex targets mTORC1 to the lysosomal surface and is necessary for its activation by amino acids. Cell 141: 290-303.
Sarbassov DD, Ali SM, Kim DH, Guertin DA, Latek RR, Erdjument-Bromage H, Tempst P, Sabatini DM. 2004. Rictor, a novel binding partner of mTOR, defines a rapamycin-insensitive and raptor-independent pathway that regulates the cytoskeleton. Curr Biol 14: 1296-1302.

Sarbassov DD, Guertin DA, Ali SM, Sabatini DM. 2005. Phosphorylation and regulation of Akt/PKB by the rictor-mTOR complex. Science 307: 1098-1101.

Sarbassov DD, Ali SM, Sengupta S, Sheen JH, Hsu PP, Bagley AF, Markhard AL, Sabatini DM. 2006. Prolonged rapamycin treatment inhibits mTORC2 assembly and Akt/ PKB. Mol Cell 22: 159-168.

Schalm SS, Blenis J. 2002. Identification of a conserved motif required for mTOR signaling. Curr Biol 12: 632-639.

Schalm SS, Fingar DC, Sabatini DM, Blenis J. 2003. TOS motif-mediated raptor binding regulates $4 \mathrm{E}-\mathrm{BP} 1$ multisite phosphorylation and function. Curr Biol 13: 797806.

Scheper GC, Morrice NA, Kleijn M, Proud CG. 2001. The mitogen-activated protein kinase signal-integrating kinase Mnk2 is a eukaryotic initiation factor 4E kinase with high levels of basal activity in mammalian cells. Mol Cell Biol 21: 743-754.

Scheper GC, van Kollenburg B, Hu J, Luo Y, Goss DJ, Proud CG. 2002. Phosphorylation of eukaryotic initiation factor $4 \mathrm{E}$ markedly reduces its affinity for capped mRNA. J Biol Chem 277: 3303-3309.

Schwanhausser B, Busse D, Li N, Dittmar G, Schuchhardt J, Wolf J, Chen W, Selbach M. 2011. Global quantification of mammalian gene expression control. Nature 473: 337-342.

Sengupta S, Peterson TR, Sabatini DM. 2010. Regulation of the mTOR complex 1 pathway by nutrients, growth factors, and stress. Mol Cell 40: 310-322.

Shahbazian D, Roux PP, Mieulet V, Cohen MS, Raught B, Taunton J, Hershey JW, Blenis J, Pende M, Sonenberg N. 2006. The mTOR/PI3K and MAPK pathways converge on eIF4B to control its phosphorylation and activity. EMBO J 25: 2781-2791.

Shahbazian D, Parsyan A, Petroulakis E, Topisirovic I, Martineau Y, Gibbs BF, Svitkin Y, Sonenberg N. 2010. Control of cell survival and proliferation by mammalian eukaryotic initiation factor 4B. Mol Cell Biol 30: 1478-1485.

Shaw RJ. 2009. LKB1 and AMP-activated protein kinase control of mTOR signalling and growth. Acta Physiol (Oxf) 196: 65-80.

Shaw RJ, Cantley LC. 2006. Ras, PI(3)K and mTOR signalling controls tumour cell growth. Nature 441: 424-430.

Shaw RJ, Bardeesy N, Manning BD, Lopez L, Kosmatka M, DePinho RA, Cantley LC. 2004. The LKB1 tumor suppressor negatively regulates mTOR signaling. Cancer Cell 6: 91-99.

Shi J, Feng Y, Goulet AC, Vaillancourt RR, Sachs NA, Hershey JW, Nelson MA. 2003. The p34cdc2-related cyclindependent kinase 11 interacts with the p47 subunit of eukaryotic initiation factor 3 during apoptosis. J Biol Chem 278: 5062-5071.

Shi J, Hershey JW, Nelson MA. 2009. Phosphorylation of the eukaryotic initiation factor $3 \mathrm{f}$ by cyclin-dependent kinase 11 during apoptosis. FEBS Lett 583: 971-977. 
P.P. Roux and I. Topisirovic

Shima H, Pende M, Chen Y, Fumagalli S, Thomas G, Kozma SC. 1998. Disruption of the $\mathrm{p} 70(\mathrm{~s} 6 \mathrm{k}) / \mathrm{p} 85$ (s6k) gene reveals a small mouse phenotype and a new functional S6 kinase. EMBO J 17: 6649-6659.

Shin S, Wolgamott L, Yu Y, Blenis J, Yoon SO. 2011. Glycogen synthase kinase (GSK)-3 promotes p70 ribosomal protein S6 kinase (p70S6K) activity and cell proliferation. Proc Natl Acad Sci 108: 1204-1213.

Shor B, Wu J, Shakey Q, Toral-Barza L, Shi C, Follettie M, Yu K. 2010. Requirement of the mTOR kinase for the regulation of Mafl phosphorylation and control of RNA polymerase III-dependent transcription in cancer cells. Biol Chem 285: 15380-15392.

Silvera D, Formenti SC, Schneider RJ. 2010. Translational control in cancer. Nat Rev Cancer 10: 254-266.

Skogerson L, Moldave K. 1968. Characterization of the interaction of aminoacyltransferase II with ribosomes. Binding of transferase II and translocation of peptidyl transfer ribonucleic acid. J Biol Chem 243: 5354-5360.

Slepenkov SV, Darzynkiewicz E, Rhoads RE. 2006. Stoppedflow kinetic analysis of eIF4E and phosphorylated eIF4E binding to cap analogs and capped oligoribonucleotides: Evidence for a one-step binding mechanism. J Biol Chem 281: 14927-14938.

Soliman GA, Acosta-Jaquez HA, Dunlop EA, Ekim B, Maj NE, Tee AR, Fingar DC. 2010. mTOR Ser-2481 autophosphorylation monitors mTORC-specific catalytic activity and clarifies rapamycin mechanism of action. J Biol Chem 285: 7866-7879.

Sonenberg N. 2008. eIF4E, the mRNA cap-binding protein: From basic discovery to translational research. Biochem Cell Biol 86: 178-183.

Sonenberg N, Hinnebusch AG. 2009. Regulation of translation initiation in eukaryotes: Mechanisms and biological targets. Cell 136: 731-745.

* Sonenberg N, Mathews MB, Hershey JWB. 2012. Principles of translational control. Cold Spring Harb Perspect Biol doi: $10.1101 /$ cshperspect.a011528.

Stipanuk MH. 2009. Macroautophagy and its role in nutrient homeostasis. Nutr Rev 67: 677-689.

Sutherland C, Leighton IA, Cohen P. 1993. Inactivation of glycogen synthase kinase- 3 beta by phosphorylation: New kinase connections in insulin and growth-factor signalling. Biochem J 296: 15-19.

Svitkin YV, Pause A, Haghighat A, Pyronnet S, Witherell G, Belsham GJ, Sonenberg N. 2001. The requirement for eukaryotic initiation factor $4 \mathrm{~A}(\mathrm{elF} 4 \mathrm{~A})$ in translation is in direct proportion to the degree of mRNA $5^{\prime}$ secondary structure. RNA 7: 382-394.

Tang H, Hornstein E, Stolovich M, Levy G, Livingstone M, Templeton D, Avruch J, Meyuhas O. 2001. Amino acidinduced translation of TOP mRNAs is fully dependent on phosphatidylinositol 3-kinase-mediated signaling, is partially inhibited by rapamycin, and is independent of S6K1 and rpS6 phosphorylation. Mol Cell Biol 21: 86718683.

Thedieck K, Polak P, Kim ML, Molle KD, Cohen A, Jeno P, Arrieumerlou C, Hall MN. 2007. PRAS40 and PRR5-like protein are new $\mathrm{mTOR}$ interactors that regulate apoptosis. PLoS ONE 2: e1217.
Topisirovic I, Ruiz-Gutierrez M, Borden KL. 2004. Phosphorylation of the eukaryotic translation initiation factor eIF4E contributes to its transformation and mRNA transport activities. Cancer Res 64: 8639-8642.

Topisirovic I, Svitkin YV, Sonenberg N, Shatkin AJ. 2011. Cap and cap-binding proteins in the control of gene expression. RNA 2: 277-298.

Ueda T, Watanabe-Fukunaga R, Fukuyama H, Nagata S, Fukunaga R. 2004. Mnk2 and Mnk1 are essential for constitutive and inducible phosphorylation of eukaryotic initiation factor $4 \mathrm{E}$ but not for cell growth or development. Mol Cell Biol 24: 6539-6549.

Vander Haar E, Lee SI, Bandhakavi S, Griffin TJ, Kim DH. 2007. Insulin signalling to mTOR mediated by the Akt/ PKB substrate PRAS40. Nat Cell Biol 9: 316-323.

van Gorp AG, van der Vos KE, Brenkman AB, Bremer A, van den Broek N, Zwartkruis F, Hershey JW, Burgering BM, Calkhoven CF, Coffer PJ. 2009. AGC kinases regulate phosphorylation and activation of eukaryotic translation initiation factor 4B. Oncogene 28: 95-106.

Walsh D, Mohr I. 2004. Phosphorylation of eIF4E by Mnk-1 enhances HSV-1 translation and replication in quiescent cells. Genes Dev 18: 660-672.

Wang X, Campbell LE, Miller CM, Proud CG. 1998. Amino acid availability regulates p70 S6 kinase and multiple translation factors. Biochem J 334 (Pt 1): 261-267.

Wang X, Li W, Williams M, Terada N, Alessi DR, Proud CG. 2001a. Regulation of elongation factor 2 kinase by p90(RSK1) and p70 S6 kinase. EMBO J 20: 4370-4379.

Wang X, Paulin FE, Campbell LE, Gomez E, O'Brien K, Morrice N, Proud CG. 2001b. Eukaryotic initiation factor 2B: Identification of multiple phosphorylation sites in the epsilon-subunit and their functions in vivo. $E M B O$ J 20: 4349-4359.

Wang X, Li W, Parra JL, Beugnet A, Proud CG. 2003. The C terminus of initiation factor $4 \mathrm{E}$-binding protein 1 contains multiple regulatory features that influence its function and phosphorylation. Mol Cell Biol 23: 1546-1557.

Wang X, Beugnet A, Murakami M, Yamanaka S, Proud CG. 2005. Distinct signaling events downstream of mTOR cooperate to mediate the effects of amino acids and insulin on initiation factor $4 \mathrm{E}$-binding proteins. Mol Cell Biol 25: 2558-2572.

Wang L, Harris TE, Roth RA, Lawrence JC Jr. 2007. PRAS40 regulates mTORC1 kinase activity by functioning as a direct inhibitor of substrate binding. J Biol Chem 282: 20036-20044.

Waskiewicz AJ, Flynn A, Proud CG, Cooper JA. 1997. Mitogen-activated protein kinases activate the serine/threonine kinases Mnk1 and Mnk2. Embo J 16: 1909-1920.

Wei Y, Tsang CK, Zheng XF. 2009. Mechanisms of regulation of RNA polymerase III-dependent transcription by TORC1. EMBO J 28: 2220-2230.

Wek RC, Jiang HY, Anthony TG. 2006. Coping with stress: eIF2 kinases and translational control. Biochem Soc Trans 34(Pt 1): 7-11.

Welsh GI, Miller CM, Loughlin AJ, Price NT, Proud CG. 1998. Regulation of eukaryotic initiation factor eIF2B: Glycogen synthase kinase-3 phosphorylates a conserved serine which undergoes dephosphorylation in response to insulin. FEBS Lett 421: 125-130. 
Wendel HG, Silva RL, Malina A, Mills JR, Zhu H, Ueda T, Watanabe-Fukunaga R, Fukunaga R, Teruya-Feldstein J, Pelletier J, et al. 2007. Dissecting eIF4E action in tumorigenesis. Genes Dev 21: 3232-3237.

Widmann C, Gibson S, Jarpe MB, Johnson GL. 1999. Mitogen-activated protein kinase: Conservation of a threekinase module from yeast to human. Physiol Rev 79: $143-180$.

Woo SY, Kim DH, Jun CB, Kim YM, Haar EV, Lee SI, Hegg JW, Bandhakavi S, Griffin TJ. 2007. PRR5, a novel component of mTOR complex 2, regulates platelet-derived growth factor receptor beta expression and signaling. $J$ Biol Chem 282: 25604-25612.

Woods YL, Cohen P, Becker W, Jakes R, Goedert M, Wang X, Proud CG. 2001. The kinase DYRK phosphorylates protein-synthesis initiation factor eIF2Bepsilon at Ser539 and the microtubule-associated protein tau at Thr212: Potential role for DYRK as a glycogen synthase kinase 3-priming kinase. Biochem J 355 (Pt 3): 609-615.

Worch J, Tickenbrock L, Schwable J, Steffen B, Cauvet T, Mlody B, Buerger H, Koeffler HP, Berdel WE, Serve $\mathrm{H}$, et al. 2004. The serine-threonine kinase MNK1 is post-translationally stabilized by PML-RARalpha and regulates differentiation of hematopoietic cells. Oncogene 23: 9162-9172.

Wullschleger S, Loewith R, Hall MN. 2006. TOR signaling in growth and metabolism. Cell 124: 471-484.

Yamagata K, Sanders LK, Kaufmann WE, Yee W, Barnes CA, Nathans D, Worley PF. 1994. rheb, a growth factor- and synaptic activity-regulated gene, encodes a novel Ras-related protein. J Biol Chem 269: 16333-16339.

Yang HS, Jansen AP, Komar AA, Zheng X, Merrick WC, Costes S, Lockett SJ, Sonenberg N, Colburn NH. 2003. The transformation suppressor Pdcd4 is a novel eukaryotic translation initiation factor $4 \mathrm{~A}$ binding protein that inhibits translation. Mol Cell Biol 23: 26-37.

Yea SS, Fruman DA. 2011. Cell signaling. New mTOR targets Grb attention. Science 332: 1270-1271.
Yip CK, Murata K, Walz T, Sabatini DM, Kang SA. 2010. Structure of the human mTOR complex I and its implications for rapamycin inhibition. Mol Cell 38: 768-774.

Zeniou M, Ding T, Trivier E, Hanauer A. 2002. Expression analysis of RSK gene family members: The RSK2 gene, mutated in Coffin-Lowry syndrome, is prominently expressed in brain structures essential for cognitive function and learning. Hum Mol Genet 11: 2929-2940.

Zetterberg A, Larsson O, Wiman KG. 1995. What is the restriction point? Curr Opin Cell Biol 7: 835-842.

Zhang L, Smit-McBride Z, Pan X, Rheinhardt J, Hershey JW. 2008. An oncogenic role for the phosphorylated h-subunit of human translation initiation factor eIF3. J Biol Chem 283: 24047-24060.

Zhao J, Yuan X, Frodin M, Grummt I. 2003. ERK-dependent phosphorylation of the transcription initiation factor TIF-IA is required for RNA polymerase I transcription and cell growth. Mol Cell 11: 405-413.

Zhao Y, Xiong X, Sun Y. 2011. DEPTOR, an mTOR inhibitor, is a physiological substrate of $\operatorname{SCF}($ betaTrCP) E3 ubiquitin ligase and regulates survival and autophagy. Mol Cell 44: 304-316.

Zhou M, Sandercock AM, Fraser CS, Ridlova G, Stephens E, Schenauer MR, Yokoi-Fong T, Barsky D, Leary JA, Hershey JW, et al. 2008. Mass spectrometry reveals modularity and a complete subunit interaction map of the eukaryotic translation factor eIF3. Proc Natl Acad Sci 105: 18139-18144.

Zinzalla V, Stracka D, Oppliger W, Hall MN. 2011. Activation of mTORC2 by association with the ribosome. Cell 144: 757-768.

Zoncu R, Bar-Peled L, Efeyan A, Wang S, Sancak Y, Sabatini DM. 2011a. mTORC1 senses lysosomal amino acids through an inside-out mechanism that requires the vacuolar H-ATPase. Science 334: 678-683.

Zoncu R, Efeyan A, Sabatini DM. 2011b. mTOR: From growth signal integration to cancer, diabetes and ageing. Nat Rev Mol Cell Biol 12: 21-35. 


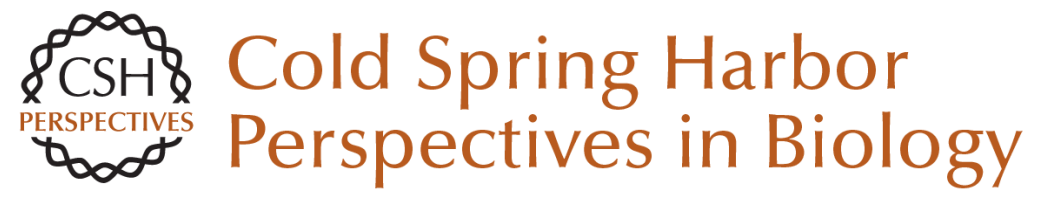

\section{Regulation of mRNA Translation by Signaling Pathways}

Philippe P. Roux and Ivan Topisirovic

Cold Spring Harb Perspect Biol 2012; doi: 10.1101/cshperspect.a012252 originally published online August 10, 2012

\section{Subject Collection Protein Synthesis and Translational Control}

Tinkering with Translation: Protein Synthesis in Virus-Infected Cells

Derek Walsh, Michael B. Mathews and lan Mohr

Translational Control in Cancer Etiology

Davide Ruggero

A Molecular Link between miRISCs and Deadenylases Provides New Insight into the

Mechanism of Gene Silencing by MicroRNAs Joerg E. Braun, Eric Huntzinger and Elisa Izaurralde

Imaging Translation in Single Cells Using Fluorescent Microscopy Jeffrey A. Chao, Young J. Yoon and Robert $H$. Singer

mRNA Localization and Translational Control in Drosophila Oogenesis Paul Lasko

P-Bodies and Stress Granules: Possible Roles in the Control of Translation and mRNA Degradation Carolyn J. Decker and Roy Parker

Protein Secretion and the Endoplasmic Reticulum Adam M. Benham

From Cis-Regulatory Elements to Complex RNPs and Back

Fátima Gebauer, Thomas Preiss and Matthias W. Hentze
Toward a Genome-Wide Landscape of

Translational Control

Ola Larsson, Bin Tian and Nahum Sonenberg

The Current Status of Vertebrate Cellular mRNA

IRESs

Richard J. Jackson

Principles of Translational Control: An Overview John W.B. Hershey, Nahum Sonenberg and Michael B. Mathews

Regulation of mRNA Translation by Signaling Pathways

Philippe P. Roux and Ivan Topisirovic

The Mechanism of Eukaryotic Translation Initiation: New Insights and Challenges Alan G. Hinnebusch and Jon R. Lorsch

Single-Molecule Analysis of Translational Dynamics Alexey Petrov, Jin Chen, Seán O'Leary, et al.

Cytoplasmic RNA-Binding Proteins and the Control of Complex Brain Function Jennifer C. Darnell and Joel D. Richter

The Elongation, Termination, and Recycling

Phases of Translation in Eukaryotes

Thomas E. Dever and Rachel Green

For additional articles in this collection, see http://cshperspectives.cshlp.org/cgi/collection/

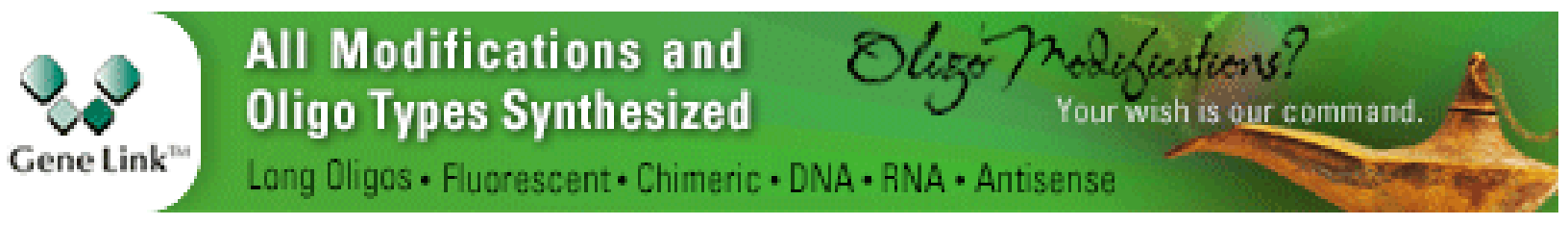


For additional articles in this collection, see http://cshperspectives.cshlp.org/cgi/collection/

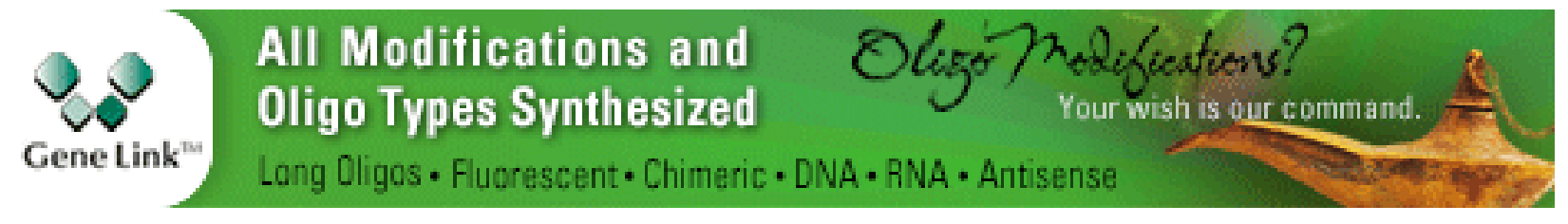

Copyright @ 2012 Cold Spring Harbor Laboratory Press; all rights reserved 